\title{
The adipocyte: a model for integration of endocrine and metabolic signaling in energy metabolism regulation
}

\author{
GEMA FRÜHBECK, ${ }^{1,2}$ JAVIER GÓMEZ-AMBROSI, ${ }^{2}$ \\ FRANCISCO JOSÉ MURUZÁBAL ${ }^{3}$ AND MARÍA ANGELA BURRELL ${ }^{3}$ \\ ${ }^{1}$ Department of Endocrinology, Clínica Universitaria de Navarra, ${ }^{2}$ Metabolic Research Laboratory, \\ and ${ }^{3}$ Department of Histology and Pathology, University of Navarra, 31008 Pamplona, Spain
}

\begin{abstract}
Frühbeck, Gema, Javier Gómez-Ambrosi, Francisco José Muruzábal, and María Angela Burrell. The adipocyte: a model for integration of endocrine and metabolic signaling in energy metabolism regulation. Am J Physiol Endocrinol Metab 280: E827-E847, 2001.-The ability to ensure continous availability of energy despite highly variable supplies in the environment is a major determinant of the survival of all species. In higher organisms, including mammals, the capacity to efficiently store excess energy as triglycerides in adipocytes, from which stored energy could be rapidly released for use at other sites, was developed. To orchestrate the processes of energy storage and release, highly integrated systems operating on several physiological levels have evolved. The adipocyte is no longer considered a passive bystander, because fat cells actively secrete many members of the cytokine family, such as leptin, tumor necrosis factor- $\alpha$, and interleukin-6, among other cytokine signals, which influence peripheral fuel storage, mobilization, and combustion, as well as energy homeostasis. The existence of a network of adipose tissue signaling pathways, arranged in a hierarchical fashion, constitutes a metabolic repertoire that enables the organism to adapt to a wide range of different metabolic challenges, such as starvation, stress, infection, and short periods of gross energy excess.
\end{abstract}

leptin; tumor necrosis factor- $\alpha$; interleukins; obesity; insulin resistance

\section{OVERVIEW}

Unraveling the diverse hormonal and neuroendocrine systems that regulate energy balance and body fat has been a long-standing challenge in biology, with obesity as an increasingly important public health focus (12). Adipose tissue is the body's largest energy reservoir. For example, an adult with $15 \mathrm{~kg}$ of body fat has $>460 \mathrm{MJ}$ (110,000 kcal) of lipid fuel stores, which could provide $8.37 \mathrm{MJ}(2,000 \mathrm{kcal})$ daily for $\sim 2 \mathrm{mo}(75$, 129). The primary role of adipocytes is to store triacylglycerol during periods of caloric excess and to mobilize this reserve when expenditure exceeds intake. Mature adipocytes are uniquely equipped to perform these functions. They possess the full complement of enzymes and regulatory proteins needed to carry out both lipolysis and de novo lipogenesis. In fat cells, the regulation of these processes is exquisitely responsive to hormones, cytokines, and other factors that are involved in energy metabolism (87). The ability to carry out these functions is acquired during embryonic de- velopment in preparation for the postnatal period, when an adipose energy reserve becomes necessary. Major expansion of the white adipocyte population is delayed until shortly after birth, although preadipocytes first appear late in embryonic life (22).

The present review will focus on the evidence for the synthesis and secretion by white adipocytes of endocrine, paracrine, and autocrine signals implicated in energy balance regulation, with special reference to cytokines. The interactions between these adipose tissue-derived mediators and other neuroendocrine pathways will be examined. Furthermore, the metabolic alterations in adipose tissue signaling leading to obesity and insulin resistance will be described.

\section{WHITE ADIPOSE TISSUE SIGNALS}

Adipocytes, which vary enormously in size (20-200 $\mu \mathrm{m}$ in diameter), are embedded in a connective tissue matrix and are uniquely adapted to store and release energy. Surplus energy is assimilated by fat cells and stored as triglycerides in lipid droplets. To accommo- 
date the lipids, adipocytes are capable of changing their diameter 20 -fold and their volumes by several thousandfold. Because $\sim 90 \%$ of the cell volume is a lipid droplet, the nucleus and the thin cytoplasmic rim are pushed to the periphery of the adipocytes. White adipose tissue is actively involved in cell function regulation through a complex network of endocrine, paracrine, and autocrine signals that influence the response of many tissues, including hypothalamus, pancreas, liver, skeletal muscle, kidneys, endothelium, and immune system, among others. Until recently, the adipocyte has been considered to be only a passive tissue for the storage of excess energy in the form of fat (37). However, there is now compelling evidence that adipocytes act as endocrine secretory cells $(37,143)$. It has been shown that several hormones, growth factors, and cytokines are actually expressed in white adipose tissue (Tables 1 and 2). In a dynamic view of the adipocyte, a wide range of signals emanates from white adipose tissue, such as leptin, tumor necrosis factor- $\alpha$ (TNF- $\alpha$ ), interleukin-6 (IL-6), and their respective soluble receptors. White adipose tissue also secretes important regulators of lipoprotein metabolism, like lipoprotein lipase (LPL), apolipoprotein $\mathrm{E}$ (apoE), and cholesteryl ester transfer protein (CETP). The increasing number of products secreted by adipocytes also includes angiotensinogen, plasminogen activator inhibitor-1 (PAI-1), tissue factor, and transforming growth factor- $\beta$ (TGF- $\beta$ ). Nitric oxide synthase (NOS) has also been reported to be expressed in rat white adipose tissue, indicating that adipocytes are a potential source of NO production (131). Recently, evidence for an involvement of $\mathrm{NO}$ in both rat and human lipolysis has been published $(3,48)$. Interestingly, leptin immunolabeling of white adipocytes exhibits an absolutely superimposable staining pattern to that of inducible NOS (iNOS), as can be observed in histological sections (Fig. 1 and 2). The role of insulin-like growth factor I (IGF-I), glucocorticoids, and sex steroids in adipose tissue proliferation, heterogeneity, and distribution is beginning to be better understood. However, the influence of acylation-stimulating protein (ASP), adipophilin, adipoQ, adipsin, monobutyrin, agouti protein, and factors related to proinflammatory and immune processes still remains to be fully elucidated (14). These relationships show that white adipose tissue lies at the heart of a network of autocrine, paracrine, and endocrine signals (Fig. 3). Through the existence of a network of local and systemic signals, which interact with neuroendocrine regulators, adipose tissue signaling pathways, arranged in a hierarchical fashion, constitute one of the voices of the body that enable the organism to adapt to a range of different metabolic challenges, such as starvation, stress, and infection, as well as periods of gross energy excess.

\section{ADIPOCYTE SECRETORY PRODUCTS AND THEIR METABOLIC EFFECTS}

Adipocytes produce a great number of factors that serve as feedback signals to regulate adipose tisssue metabolism. Undoubtedly, the development of sophisticated molecular techniques has contributed to the identification of many of the secretory products of adipose tissue.

\section{Adipsin}

Adipsin is a serine protease secreted by fat cells. It was originally identified as a highly differentiationdependent gene in 3T3-L1 adipocytes (21). Expression of adipsin is markedly downregulated in rodent obesities, probably as a consequence of increased concentra-

Table 1. Proteins secreted by adipose tissue to the bloodstream

\begin{tabular}{|c|c|c|}
\hline Molecule & Function/Effect & Reference \\
\hline Leptin & Signals to the brain about body fat stores & 44,196 \\
\hline & Regulation of appetite and energy expenditure & \\
\hline TNF- $\alpha$ & $\begin{array}{l}\text { Interferes with insulin receptor signaling and is a possible cause of the development of insulin } \\
\text { resistance in obesity }\end{array}$ & 62,65 \\
\hline IL-6 & Implicated in host defense and in glucose and lipid metabolism & 111 \\
\hline PAI-1 & Potent inhibitor of the fibrinolytic system & 146 \\
\hline Tissue factor & Major cellular initiator of the coagulation cascade & 41 \\
\hline Angiotensinogen & Precursor of angiotensin II. Regulator of blood pressure and electrolyte homeostasis & 76 \\
\hline Adipsin & $\begin{array}{l}\text { Possible link between the activation of the alternative complement pathway and adipose tissue } \\
\text { metabolism }\end{array}$ & 19,41 \\
\hline ASP & Influences the rate of triacylglycerol synthesis in adipose tissue & 41 \\
\hline Adipophilin & May be a specific marker for lipid accumulation in the cells & 59 \\
\hline $\begin{array}{l}\text { AdipoQ/apM1/ } \\
\text { Adiponectin/Acrp }\end{array}$ & $\begin{array}{l}\text { May play a role in the pathogenesis of Familial Combined Hyperlipidemia and associated insulin } \\
\text { resistance }\end{array}$ & 67 \\
\hline $\mathrm{PGI}_{2}$ and $\mathrm{PGF}_{2 \alpha}$ & $\begin{array}{l}\text { Implicated in regulatory functions such as inflammation and blood clotting, ovulation, } \\
\text { menstruation, and acid secretion }\end{array}$ & 111 \\
\hline TGF $\beta$ & $\begin{array}{l}\text { Regulates a wide variety of biological responses, including proliferation, differentiation, apoptosis, } \\
\text { and development }\end{array}$ & 154 \\
\hline IGF-I & $\begin{array}{l}\text { Stimulates proliferation of a wide variety of cells and mediates many of the effects of growth } \\
\text { hormone }\end{array}$ & 18,141 \\
\hline MIF & Involved in proinflammatory processes and immunoregulation & 134 \\
\hline
\end{tabular}

TNF- $\alpha$, tumor necrosis factor- $\alpha$; IL-6, interleukin-6; PAI-1, plasminogen activator inhibitor-1; ASP, acylation-stimulating protein; Acrp, adipocyte complement-related protein, or AdipoQ; apM1, adipose most abundant gene transcript $1 ; \mathrm{PGI}_{2}$ and $\mathrm{PGF}_{2 \alpha}$, prostaglandins $\mathrm{I}_{2}$ and $\mathrm{F}_{2 \alpha}$, respectively; TGF- $\beta$, transforming growth factor- $\beta$; IGF-I, insulin-like growth factor I; MIF, macrophage inhibitory factor. 
Table 2. White adipocyte receptors

\begin{tabular}{|c|c|c|}
\hline Receptor & Main Effect of Receptor Activation on Adipocyte Metabolism & Reference \\
\hline \multicolumn{3}{|c|}{ Hormone-cytokine receptors } \\
\hline Leptin (OB-R) & $\begin{array}{l}\text { Stimulation of lipolysis } \\
\text { Autocrine regulation of leptin expression }\end{array}$ & $1,6,43,195$ \\
\hline Insulin & $\begin{array}{l}\text { Inhibition of lipolysis and stimulation of lipogenesis } \\
\text { Induction of glucose uptake and oxidation } \\
\text { Stimulation of leptin expression }\end{array}$ & 82 \\
\hline Glucagon & Stimulation of lipolysis & 73 \\
\hline IGF-I and -II & $\begin{array}{l}\text { Inhibition of lipolysis } \\
\text { Stimulation of glucose transport and oxidation }\end{array}$ & 162 \\
\hline GH & $\begin{array}{l}\text { Induction of leptin and IGF-I expression } \\
\text { Stimulation of lipolysis }\end{array}$ & 176 \\
\hline $\mathrm{TSH}$ & $\begin{array}{l}\text { Regulation of adipocyte differentiation } \\
\text { Regulation of lipolysis }\end{array}$ & 34 \\
\hline Prostaglandin & $\begin{array}{l}\text { Strong antilypolitic effects }\left(\mathrm{PGE}_{2}\right) \\
\text { Modulation of preadipocyte differentiation }\left(\mathrm{PGF}_{2 \alpha} \text { and } \mathrm{PGI}_{2}\right)\end{array}$ & 41 \\
\hline $\mathrm{TNF}-\alpha$ & $\begin{array}{l}\text { Stimulation of lipolysis } \\
\text { Regulation of leptin secretion } \\
\text { Potent inhibition of adipocyte differentiation } \\
\text { Involvement in development of insulin resistance }\end{array}$ & 56,68 \\
\hline IL-6 & $\begin{array}{l}\text { LPL activity inhibition } \\
\text { Induction of lipolysis }\end{array}$ & 111 \\
\hline Adenosine & Inhibition of lipolysis & 174 \\
\hline Gastrin/CCK-B & Regulation of expression and secretion of leptin & 41 \\
\hline GIP & $\begin{array}{l}\text { Fatty acid and triglyceride synthesis stimulation } \\
\text { Amplification of insulin effects }\end{array}$ & 187,188 \\
\hline GLP-1 & $\begin{array}{l}\text { Regulation of glycogen synthesis } \\
\text { Enhancement of insulin-stimulated glucose metabolism }\end{array}$ & 29 \\
\hline NPY-Y1 & $\begin{array}{l}\text { Inhibition of lipolysis } \\
\text { Induction of leptin expression }\end{array}$ & 31 \\
\hline ANP & $\begin{array}{l}\text { Oxidative glucose metabolism modulation (via NPR-A) } \\
\text { Clearance of ANP (via NPR-C) }\end{array}$ & 139 \\
\hline Angiotensin II & $\begin{array}{l}\text { Increase of lipogenesis } \\
\text { Stimulation of prostacyclin production by mature fat cells } \\
\text { Interaction with insulin in regulation of adipocyte metabolism }\end{array}$ & 76,197 \\
\hline EGF & $\begin{array}{l}\text { Regulation of adipocyte differentiation } \\
\text { Interference with the lipolytic effect of catecholamines }\end{array}$ & 57,141 \\
\hline PDGF & Regulation of adipocyte differentiation & 41,57 \\
\hline FGF & Regulation of adipocyte differentiation & 57,115 \\
\hline TGF $\beta$ & Potent inhibition of adipocyte differentiation & 137,154 \\
\hline \multicolumn{3}{|c|}{ Catecholamine-nervous system receptors } \\
\hline$\beta_{1}, \beta_{2}, \beta_{3},\left(\beta_{4} ?\right)$ & $\begin{array}{l}\text { Stimulation of lipolysis } \\
\text { Induction of thermogenesis } \\
\text { Reduction of leptin mRNA levels }\end{array}$ & 91 \\
\hline$\alpha_{1}$ & Induction of inositol phosphate production and $\mathrm{PKC}$ activation & 91,164 \\
\hline$\alpha_{2}$ & $\begin{array}{l}\text { Inhibition of lipolysis } \\
\text { Regulation of preadipocyte growth }\end{array}$ & 91 \\
\hline $\begin{array}{l}\text { nicotinic ? } \\
\text { muscarinic ? }\end{array}$ & $\begin{array}{l}\text { Stimulation of lipolysis } \\
\text { Inhibition of lipolysis }\end{array}$ & $\begin{array}{l}12,22 \\
41\end{array}$ \\
\hline \multicolumn{3}{|c|}{ Nuclear receptors } \\
\hline $\begin{array}{l}\text { PPAR } \gamma \\
\text { RAR/RXR } \\
\mathrm{T}_{3}\end{array}$ & $\begin{array}{l}\text { Induction of adipocyte differentiation and insulin sensitivity } \\
\text { Regulation of adipocyte differentiation } \\
\text { Stimulation of lipolysis } \\
\text { Regulation of leptin secretion } \\
\text { Induction of adipocyte differentiation } \\
\text { Regulation of insulin effects }\end{array}$ & $\begin{array}{l}91,192 \\
177 \\
41,111\end{array}$ \\
\hline Glucocorticoids & Stimulation of adipocyte differentiation & 12,141 \\
\hline Androgen & $\begin{array}{l}\text { Control of adipose tissue development (antiadipogenic signals) } \\
\text { Modulation of } o b \text { gene expression }\end{array}$ & $27,87,100$ \\
\hline Estrogen & $\begin{array}{l}\text { Control of adipose tissue development (proadipogenic signals) } \\
\text { Modulation of } o b \text { gene expression }\end{array}$ & $12,27,87$ \\
\hline $\begin{array}{l}\text { Progesterone } \\
\text { Vitamin D }\end{array}$ & $\begin{array}{l}\text { Regulation of fat metabolism and distribution } \\
\text { Inhibition of adipocyte differentiation }\end{array}$ & $\begin{array}{l}87,117 \\
79\end{array}$ \\
\hline \multicolumn{3}{|c|}{ Lipoprotein receptors } \\
\hline VLDL & $\begin{array}{l}\text { Binding and internalization of VLDL particles } \\
\text { Play a role in lipid accumulation }\end{array}$ & 163 \\
\hline LDL & Stimulation of cholesterol uptake & 88 \\
\hline HDL & Clearance and metabolism of HDL & 135 \\
\hline
\end{tabular}

OB-R, leptin receptors; GH, growth hormone; TSH, thyroid-stimulating hormone; LPL, lipoprotein lipase; CCK-B, cholecystokinin-B; GIP, gastric inhibitory peptide; GLP-1, glucagon-like peptide-1; NPY-Y1, neuropeptide Y-Y1; ANP, atrial natriuretic peptide; NPR, neuropeptide receptor; EGF, PDGF, and FGF, epidermal, platelet-derived, and fibroblast growth factors, respectively; PKC, protein kinase C; PPAR $\gamma$, peroxisome proliferator-activated receptor- $\gamma$; RAR and RXR, retinoic acid receptors; $\mathrm{T}_{3}$, triiodothyronine; VLDL, LDL, and HDL, very low density, low-density, and high-density lipoproteins, respectively. 


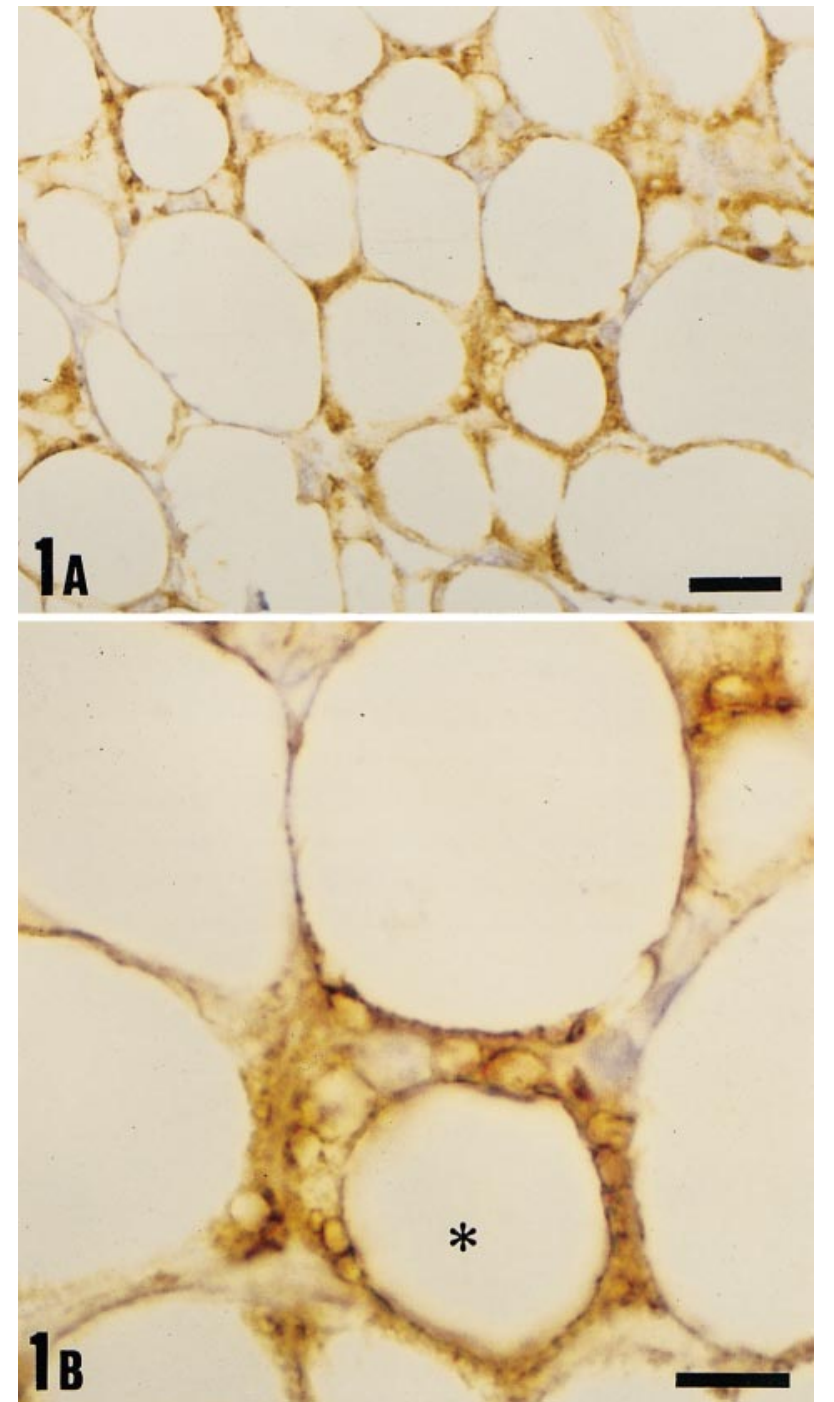

Fig. 1. Mouse visceral white adipose tissue immunostained for inducible nitric oxide synthase (iNOS). The stain appears in the thin cytoplasmic rim of the adipocytes. Note that the stain is more intense in some adipocytes $(*)$ at a multilocular stage of differentiation. $A: \times 440($ bar $=20 \mu \mathrm{m}) ; B: \times 1,100($ bar $=10 \mu \mathrm{m})$.

tions of insulin and glucocorticoids (21). Sequence comparison revealed that both murine adipsin and human adipsin were identical to complement D (165), the initial and rate-limiting enzyme in the alternative complement pathway. It was shown that fat cells synthesize all of the proteins of the alternative complement pathway, namely factors C3, D (adipsin), and B (19). The proximal, nonlytic portion of the pathway is operative in adipose tissue, and, in vitro, the proteolytic cascade results in the production, among others, of biologically active $\mathrm{C} 3 \mathrm{a}, \mathrm{Ba}$, and $\mathrm{Bb}$ (19). In cultured fat cell lines and other tissues, the activity of the alternative complement pathway requires stimulation by cytokines. However, the proximal pathway is fully functional in adipose tissue fragments, even without stimulation by cytokines, probably as a result of endogenous cytokine production. Further research is required to determine the primary functions and regula- tion of the alternative complement pathway in adipose tissue. The fact that partially acquired lipodystrophy is associated with constitutive activation of the alternative complement pathway points to a potential pathophysiological role of this pathway $(19,153)$.

\section{$A S P$}

A $14-\mathrm{kDa}$ serum protein resulting from the cleavage of the terminal arginine residue from C3a by plasma carboxypeptidases was named the acylation-stimulating protein (ASP) (41). Because C3a is the end product of the alternative complement pathway, of which factor $\mathrm{D}$, adipsin, is a main component, it was proposed that it should be designated the "adipsin-ASP pathway" (148).

Several roles for ASP in adipocyte metabolism have been proposed (41). It may be involved in the uptake and esterification of fatty acids to make triglycerides and facilitate fatty acid storage in the postprandial state. ASP increases after a fat-containing meal and stimulates triglyceride synthesis via diacylglycerol acyltransferase in adipocytes and fibroblasts. Although ASP is expressed by both preadipocytes and fibroblasts, ASP formation is, predominantly, a feature of mature and fully differentiated adipocytes (106). ASP stimulates triglyceride production to a greater extent than insulin, as well as having an additive effect with that of insulin (185). ASP also stimulates translocation of glucose transporters to the cell surface, probably by activation of the diacylglycerol-protein kinase $\mathrm{C}$ pathway (49). The fact that ASP is more potent in triglyceride synthesis stimulation supports a role for ASP in determining the rate at which fatty acids, derived from circulating triglycerides hydrolyzed by LPL, are esterified and stored in adipose tissue. Studies in ASP functional knockout mice support the putative role in triglyceride storage. Knockout mice have shown a de-

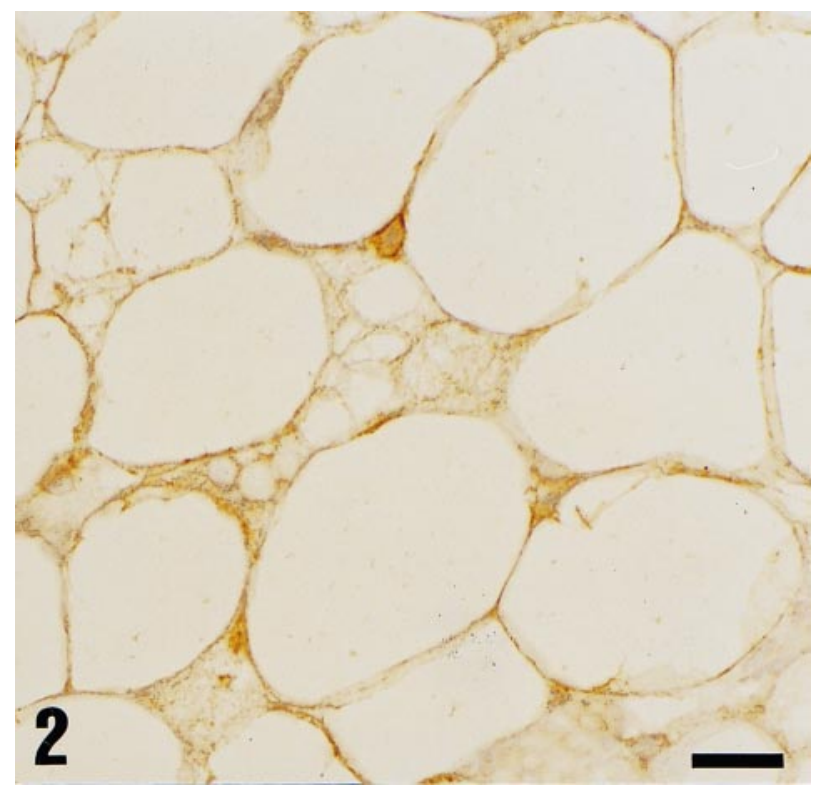

Fig. 2. Leptin immunolabeling of mouse adipocytes. The staining pattern is very similar to that of iNOS $(\times 440$; bar $=20 \mu \mathrm{m})$. 


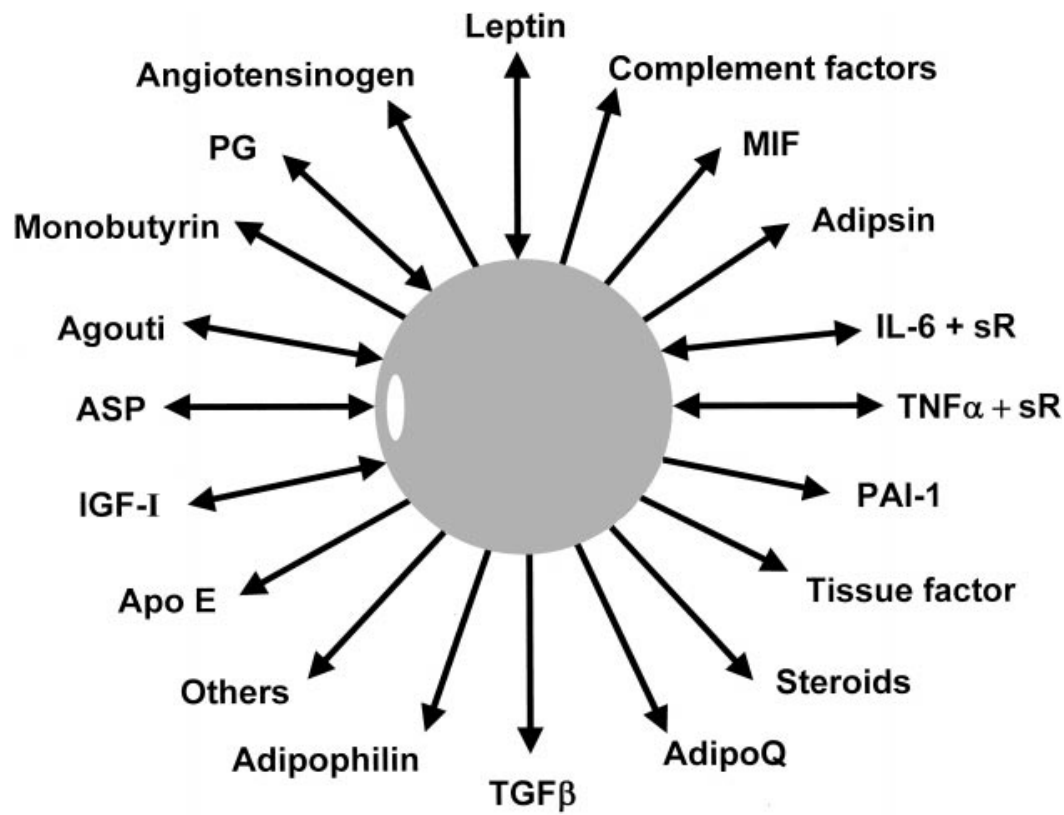

Fig. 3. Dynamic view of the adipocyte, showing signals emanating from white adipose tissue. PG, prostaglandin; ASP, acylation-stimulating protein; IGF-I, insulinlike growth factor I; apoE, apolipoprotein E; TGF- $\beta$, transforming growth factor- $\beta$; adipoQ, adipocyte complement-related protein of $30 \mathrm{kDa}$, also called Acrp30; PAI-1, plasminogen activator inhibitor-1; TNF- $\alpha$, tumor necrosis factor- $\alpha$; sR, soluble receptors; IL-6, interleukin-6; MIF, macrophage migrating inhibitory factor. layed triglyceride clearance compared with wild-type animals, and this difference is further exaggerated in female mice. The delay in triglyceride clearance may be due to the effect on LPL of increased nonesterified fatty acid concentrations. Differences between adipose tissue depots have been detected, with greater degrees of ASP binding in subcutaneous compared with omental fat, in females compared with males, and in morbidly obese compared with nonobese individuals (111).

In contrast to rodent models, serum adipsin concentrations tend to be increased in obese human subjects, whereas adipsin secretion per adipocyte is normal (149). However, when we consider that adipsin production is not elevated in proportion to the increased fat cell size, in contrast to many other adipocyte proteins, the relatively lower ASP production could play a limiting role in the triglyceride synthesis rate as fat cells enlarge. Consistent with this reasoning, in vivo studies have shown that esterification of triglyceride fatty acids released by LPL is less efficient in obese than in lean subjects $(39,127)$. Further research will help to clarify whether the major role of ASP lies in regulating local triglyceride uptake by adipocytes, as well as whether adipose tissue contributes to the pool of serum ASP and thus to systemic triacylglycerol clearance. Furthermore, the exact nature of the participation of the adipsin-ASP pathway in fat cell size regulation, together with the concrete mechanism of action of ASP, still remains unknown.

\section{Adipose Fatty Acid-Binding Protein}

Fatty acid-binding proteins are abundant low-molecular-weight cytoplasmic proteins that are thought to be involved in the intracellular transport and metabolism of fatty acids (129). Different members of this gene family are expressed in a tissue-specific manner, with several tissues expressing more than one fatty acidbinding protein type. The adipose-specific fatty acid- binding protein, also known as aP2, is expressed during adipocyte differentiation and comprises up to $6 \%$ of cytosolic protein in the mature fat cell (152). Adipose fatty acid-binding protein has been shown to be involved in intracellular trafficking and targeting of fatty acids (183). This cytosolic adipose fatty acid-binding protein is postulated to shuttle fatty acids within the aqueous cytosol toward the membranes of the relevant intracellular organelles that are involved in triglyceride synthesis or fatty acid oxidation. This transfer is believed to occur via a collisional mechanism dependent on the interaction of organelle membrane phospholipids with the basic residues of aP2, resulting in partitioning of fatty acids to organelles for metabolic utilization (183). Knockout of aP2 $\left(\mathrm{aP} 2^{-/-}\right)$results in increased expression of keratinocyte fatty acid-binding protein (63). Under normal circumstances, the keratinocyte fatty acid-binding protein is principally expressed in skin and at low levels in adipose tissue. $\mathrm{aP} 2^{-1-}$ mice show few phenotypic changes when fed a standard low-fat diet, with the exception of slightly lower plasma glucose and triglyceride concentrations in the fasted state (63). However, in contrast to wildtype controls, high-fat feeding did not lead to hyperinsulinemia and insulin resistance in $\mathrm{aP}^{-1-}$ mice, despite similarly elevated body weights. No major abnormalities in adipocyte triglyceride synthesis or lipolysis were observed in $\mathrm{aP} 2^{-1-}$ mice with compensation by keratinocyte fatty acid-binding protein (144). Therefore, deficiency of aP2 was not associated with protection from mild insulin resistance resulting from shortterm high-fat feeding. Thus, with the possible exception of de novo fatty acid synthesis, keratinocyte fatty acid-binding proteins are capable of adequately substituting for aP2. Consistent with these findings, adipose tissue expression of TNF- $\alpha$ mRNA, a proposed mediator of insulin resistance, was reported to be increased in obese wild-type mice but not in $\mathrm{aP} 2^{-/-}$ 
animals (63). These observations point to the fact that fatty acid-binding proteins are involved in mediating obesity-induced alterations in adipocyte gene expression. Furthermore, because it is reasonable to think that fatty acid-binding proteins may modulate lipolytic rate, and because increases in fatty acid flux are thought to play a role in obesity-induced insulin resistance, it was postulated that these would cause an impairment in lipolysis (63).

\section{Adipocyte Complement-Related Protein of $30 \mathrm{kDa}$}

While a substraction cDNA library of mRNAs induced during differentiation of 3T3-L1 adipocytes was screened, an adipocyte complement-related protein of $30 \mathrm{kDa}$ (Acrp30), another secretory protein belonging to the collectin family and expressed by fat cells, was found $(67,140)$. Acrp30, also called adipoQ, adiponectin, and adipose most abundant gene transcript 1 (apM1), is a relatively abundant serum protein that accounts for $\sim 0.01 \%$ of the total plasmatic protein and shows similarity to complement factor C1q. Its expression is markedly reduced in adipose tissue of obese mice and humans (140). Its function is still unknown; however, like adipsin, its secretion is modulated by insulin, pointing to the possibility that its expression is regulated by the nutritional state. Adiponectin has been shown to suppress the attachment of monocytes to endothelial cells, which is an early event in atherosclerotic vascular change, thus suggesting a protective role against vascular damage. Furthermore, decreased plasma adiponectin concentrations may be an indicator of macroangiopathy in type 2 diabetic patients (66).

\section{Agouti Protein}

The agouti gene encodes a secreted protein that acts in a paracrine manner to antagonize the melanocytestimulating hormone receptor, thereby regulating mouse coat color (102). Under normal circumstances, the agouti protein is expressed only in skin of mice. Dominant mutations in the agouti locus cause agouti to be expressed in all tissues, producing a syndrome consisting of yellow fur, obesity, hyperinsulinemia, and insulin resistance (86). Ectopic expression of agouti in transgenic mice reproduces this syndrome (86). In contrast to mice, the human agouti gene is normally expressed in adipose tissue and testis, suggesting a role for this protein in regulating adipose tissue function. The participation of the agouti protein in the development of insulin resistance has been proposed to be through increasing intracellular free calcium concentrations (191).

\section{Angiotensinogen}

Angiotensinogen is primarily synthesized by the liver, although angiotensinogen mRNA is present in several tissues, including adipose tissue (76). Angiotensinogen is the substrate of renin in the renin-angiotensin system and is converted into angiotensin I, the precursor of angiotensin II. The physiological and pathological role of angiotensinogen gene expression in adipose tissue has not been completely elucidated. Angiotensin II has been suggested to influence adipocyte differentiation by interactions with angiotensin receptors, inducing fat cells to produce prostacyclin (24). Angiotensinogen expression is increased in obesity and, in contrast to the hepatic expression, is regulated by the nutritional status (41). During fasting, a decrease in mRNA above control has been observed, which increases upon refeeding. Furthermore, these changes in gene expression are paralleled by fluctuations in angiotensinogen secretion from isolated adipocytes. Angiotensinogen mRNA in both subcutaneous and omental fat correlates with the waist-to-hip ratio, with higher mRNA expression in the omental than in the subcutaneous adipose depot (171). Angiotensinogen may play a role in local adipose tissue blood flow and, hence, in rates of fatty acid reesterification (171). Thus, by affecting both substrate availability and preadipocyte differentiation, angiotensinogen is able to regulate adipose size in response to nutritional signals.

\section{PAI-1}

PAI-1 is a member of the family of serine protease inhibitors or serpins. By inhibiting the tissue plasminogen activator, it is the main regulator of the endogenous fibrinolytic system (182). Therefore, increased concentrations of PAI-1 favor the development of thromboembolic complications. Among the multiple mechanisms that may explain the relationship between obesity and cardiovascular disease, disorders of the fibrinolytic system seem to play a key role (78). Elevated plasma concentrations of PAI-1 have been found in obese subjects. A close correlation with an abdominal pattern of adipose tissue distribution in both men and women, as well as a positive association with other components of the insulin resistance syndrome, have been reported $(78,146,170)$. The mechanisms responsible for the increase in PAI-1 are not yet completely established. Expression and secretion of PAI-1 in adipose tissue from humans and rodents have been demonstrated. However, little is known about its regulation at the adipocyte level. Insulin and TGF- $\beta$ appear to be the main inducers of PAI- 1 synthesis in adipose tissue (136). TNF- $\alpha$, as well as IL-1 $\beta$, also has a stimulatory effect on PAI-1 protein secretion and may contribute to the augmented PAI-1 concentrations observed in obesity and insulin resistance (9). Insulin has been reported to elevate PAI-1 production in cultured hepatocytes, suggesting that increased hepatic synthesis of PAI-1 might account for its elevation in obese subjects (41). Recently, however, elevated PAI-1 concentrations associated with obesity have been shown to result in part from insulin-mediated induction of PAI-1, specifically by adipocytes within the fat itself (9). It has been shown that, in dieting obese women, the decrease in PAI-1 during weight loss is more closely related to changes in fat mass than to changes in metabolic variables, suggesting a significant role of adipose tissue in regulating plasma PAI-1 concentrations (107). However, a strong correlation 
exists between PAI-1 antigen and circulating leptin concentrations irrespective of body mass index, and body fat mass seems to indicate that leptin per se may potentially increase PAI-1 in obese subjects $(25,150)$.

\section{$T G F-\beta$}

TGF- $\beta$ is a multifunctional cytokine produced by a variety of cells that is capable of regulating the growth and differentiation of numerous cell types $(137,154)$. It has been implicated in a number of biological processes, including cell adhesion and migration, extracellular matrix production, tissue remodeling, and wound repair.

TGF- $\beta$ mRNA expression has been shown to be higher in adipose tissue of $o b / o b$ and $d b / d b$ mice compared with their lean littermates (137). Moreover, this increase was due to elevated expression of TGF- $\beta$ mRNA by mature adipocytes and cells of the stromal/ vascular fraction. TNF- $\alpha$ contributes to the augmented expression of TGF- $\beta$ in adipose tissue of obese mice. In this sense, chronically elevated TNF- $\alpha$ concentrations in adipose tissue of obese individuals may act in an autocrine/paracrine manner and contribute to increased TGF- $\beta$ expression in obesity. The elevated gene expression of TGF- $\beta$ in adipose tissue may have broad implications in the pathophysiology of obesity and its associated complications. TGF- $\beta$ has been shown to increase preadipocyte cell proliferation. Thus the augmented expression of TGF- $\beta$ in the obese adipose tissue may increase adipocyte precursor cell proliferation, thereby contributing to the elevated cellularity of fat depots related to the obese phenotype. Both obesity and type 2 diabetes are also associated with characteristic long-term complications, including microvascular kidney disease. Interestingly, overexpression of TGF- $\beta$ in glomeruli has been reported (41).

As mentioned before, TGF- $\beta$ stimulates PAI-1 biosynthesis in a variety of cells, including adipocytes. Insulin failed to raise TGF- $\beta$ mRNA expression in lean mice, even though significantly increasing the expression of PAI-1 mRNA in adipose tissue (137). Administration of TGF- $\beta$ to lean mice has been shown to cause a 60-fold increase in plasmatic active PAI-1 and increased PAI-1 mRNA in adipose tissue (137). The TGF$\beta$-mediated induction of PAI-1 in 3T3-L1 adipocytes was considerably higher than the response of these cells to TNF- $\alpha$ and insulin. Similarly, the greatest PAI-1 response in adipose tissue in in vivo studies was to TGF- $\beta$ (36-fold), followed by TNF- $\alpha$ (9-fold), and insulin (7-fold) $(136,137)$.

\section{Growth Hormone}

Growth hormone $(\mathrm{GH})$ is an important regulator of body mass throughout life $(4,14)$. It has been observed that GH deficiency in both children and adults is characterized by abnormal body composition, with increased fat mass and decreased lean muscle mass. GH-deficient subjects exhibit increased visceral and subcutaneous adipose tissue depots, which are partly normalized by GH therapy $(2,4)$. Whereas subcutane- ous adipose tissue decreased by an average of $13 \%$, visceral fat depots were reduced by $30 \%$. In contrast, in patients with acromegaly, a reduced fat mass was observed to return to normal after treatment of the hormone excess by octreotide or pituitary surgery. Adipocytes have specific GH receptors, with the hormone exerting a variety of direct metabolic effects, such as inhibition of glucose uptake and stimulation of lipolysis, which may cause a net loss of stored lipids (2).

\section{Sex Steroids}

Two enzymes of relevance to sex steroid metabolism are present in adipose tissue, $17 \beta$-hydroxysteroid oxidoreductase and cytochrome- $P$-450-dependent aromatase (111). Androstenedione, synthesized in the adrenal cortex, is converted by $17 \beta$-hydroxysteroid oxidoreductase to testosterone. This same enzyme converts estrogen and estrone to estradiol. Aromatization of androgens to estrogens also takes place in white adipose tissue. The presence of estrogens in the plasma of postmenopausal women led to the discovery that adipose tissue was an active extraglandular producer of certain steroid hormones $(87,111)$. Circulating C19 precursors of adrenal origin are converted to estrone and estradiol via adipose tissue $P-450$ aromatase (111). A net release of testosterone, estradiol, and estrone from abdominal subcutaneous adipose tissue in women, but not in men, has been shown in arteriovenous studies (132). A clear sexual dimorphism in relation to the influence of sex steroids on adipose tissue function has been observed.

\section{ADIPOCYTES AS A SOURCE OF CYTOKINES}

Cytokines are defined as soluble proteins synthesized by immune or nonimmune cells, which mediate intercellular communication by transmitting information to target cells through receptor-ligand interactions. This class of mediators is represented by cytolytic, chemotactic, and immunoenhancing growth and differentiation factors. Many cytokines have physiological activities far beyond those originally discovered. A prominent role for cytokines in the regulation of energy balance has evolved from recent investigations. Proinflammatory cytokines with potent actions in host defense, like TNF- $\alpha$ and IL-6, have also important effects on both lipid and glucose metabolism $(53,111)$.

\section{$I L-6$}

The term interleukin originally described a leukocyte-derived protein with activity for other leukocytes. It is now understood that both immune and nonimmune cells synthesize interleukins and other cytokines, which have diverse biological activities.

Interleukin- 6 expression in adipose tissue. Interestingly, production of IL-6, as well as systemic concentrations, has been shown to be positively correlated with body mass index (175). As much as a third of total circulating concentrations of IL- 6 has been estimated to originate from adipose tissue $(110,184)$. In this sense, IL- 6 may be both an autocrine and a paracrine 
regulator of adipocyte function. Omental fat produces threefold more IL-6 than subcutaneous adipose tissue, and adipocytes isolated from the omental depot also secrete more IL-6 than fat cells from the subcutaneous depot (40). Although it has now been clearly established that adipocytes themselves secrete IL- 6 on a per lipid weight or per fat cell basis, this cell type accounts for only $10 \%$ of the total adipose tissue production, as evidenced by determination of IL- 6 released by intact adipose tissue fragments and isolated adipocytes prepared from omental and subcutaneous fat depots (40). Thus other cells within the adipose tissue also contribute to the high release of IL-6. This is not surprising, because IL- 6 is a multifunctional cytokine produced by many different cell types, including immune cells, fibroblasts, stromal-vascular cells, endothelial cells, myocytes, and a variety of endocrine cells (172). The amount of IL- 6 produced by adipose tissue is similar to or greater than that reported for a variety of other tissues and cells, with the concentrations of IL- 6 accumulating in adipose tissue or cell incubations (up to 75 $\mathrm{ng} / \mathrm{ml}$ ) being well within the range to elicit biological effects (51). Regardless of the cellular source of IL-6, it is interesting to note that adipose tissue may be an important source for the increased serum concentrations of IL-6 observed in obesity, with depot-specific differences in terms of both quantitative contribution to the serum pool and qualitative participation in lipid metabolism. Because the venous drainage from omental adipose tissue flows directly into the liver, the metabolic impact of IL-6 release from this fat depot may be of particular importance. In this sense, it has been shown that IL-6 increases hepatic triglyceride secretion (116) and may, therefore, contribute to the hypertriglyceridemia associated with visceral obesity.

IL-6 is secreted by adipose tissue under basal conditions. It has been shown that TNF- $\alpha$ produces a 60 -fold increase in IL-6 production in differentiated 3T3-L1 adipocytes (53). Thus it is feasible that adipose tissue TNF- $\alpha$, whose expression is elevated in obesity, induces adipocyte and nonadipocyte IL-6 expression. Other important modulators of IL-6 expression in different fat depots are glucocorticoids and catecholamines $(40,119)$. Dexamethasone markedly suppresses IL-6 production, whereas insulin has no effect, suggesting that cortisol may act physiologically in the modulation of IL-6 production. In primary cultures of murine adipocytes, norepinephrine, isoprenaline, and a $\beta_{3}$-selective agonist have been shown to stimulate IL-6 gene expression and protein secretion, whereas activation of $\alpha$-adrenergic receptors had no effect (111).

IL-6 receptors. Class I cytokine receptors are known to act through Janus kinases (JAK) and signal transducers and activators of transcription (STAT). JAK proteins are associated with membrane-proximal sequences of the receptor intracellular domain, which is phosphorylated upon ligand binding. The phosphorylated intracellular domain then provides a binding site for a STAT protein, which is activated, translocates to the nucleus, and stimulates transcription. The biolog- ical activities of IL- 6 are initiated by binding to a high-affinity receptor complex consisting of two membrane glycoproteins (160). The IL-6 receptor (IL-6R), the $80-\mathrm{kDa}$ ligand-binding component, binds IL-6 with low affinity, but the $130-\mathrm{kDa}$ signal-transducing component, gp130, although not binding free IL-6, is required for high-affinity binding of gp80-bound IL-6. It has been reported that IL-6-type cytokines use tyrosine kinases of the JAK family for signal transduction (71). Dimerization of the intracellular domains of two gp130 molecules brings the receptor-associated JAKs (JAK1, JAK2, and Tyk2) into close proximity, leading to activation via inter- or intramolecular phosphorylation and activation. Specific STAT proteins are recruited to the stimulated receptor complexes and are activated by direct phosphorylation by receptor-asscociated JAKs. The leukemia inhibitory factor (LIF), a member of the IL-6 family of cytokines, has been shown to activate the JAK/STAT pathway (71). After the activation of the signal transduction receptor gp130, LIF induces a rapid tyrosine phosphorylation of JAK1, JAK2, Tyk2, STAT1, and STAT3.

A soluble form of IL-6R (IL-6Rs), apparently arising from proteolytic cleavage of the membrane-bound receptor and with a molecular mass of $\sim 50 \mathrm{kDa}$, has been found (157). The recombinant IL-6Rs has been shown to increase the activity of IL-6 as a result of the binding of the IL-6/IL-6Rs complex to the membrane-bound gp130 (160). Elevated concentrations of IL-6 have been suggested to be associated with increased production of IL-6Rs (133). Recently, evidence for a soluble form of the gp130 receptor, which may exert antagonist properties, has also been reported (186). In humans, subcutaneous adipose tissue has been shown to release IL- 6 but not soluble receptors $(109,110)$. Therefore, a regulatory role for adipocytes in the bioavailability of cytokines has been put forward (111). However, neither the functional significance nor the regulation of soluble receptors is clearly understood.

Biological effects of IL-6. IL-6 decreases adipose tissue LPL activity and has been implicated in the fat depletion taking place during cancer cachexia and other wasting disorders $(51,158)$. Like TNF- $\alpha$, IL-6 has potent effects on adipose tissue, as evidenced by the fact that neutralization of this cytokine decreases the loss of adipose tissue during cachexia (158). It seems unlikely that this effect is mediated solely by the documented ability of IL-6 to downregulate LPL activity, implying that IL- 6 exerts other actions on adipocyte metabolism. IL- 6 is considered to be an inflammatory mediator as well as a stress-induced cytokine (189). It has pleiotropic effects on a variety of tissues, including downregulation of adipocyte LPL, stimulation of acutephase protein synthesis, increase in the activity of the hypothalamic-pituitary axis (HPA), and thermogenesis, consistent with the candidate role of corticotropinreleasing hormone $(\mathrm{CRH})$ as a common mediator of both of these actions. 
$T N F-\alpha$

TNF- $\alpha$ is a cytokine, first identified as a macrophage product implicated in the metabolic disturbances of chronic inflammation and malignancy. The biological actions of TNF- $\alpha$ include induction of insulin resistance, anorexia, and weight loss. Since the discovery that TNF- $\alpha$ is involved in the loss of body fat in the course of wasting disorders, a large number of studies investigated the physiological role of this cytokine in adipose tissue $(65,81,165)$.

$T N F$ - $\alpha$ expression in adipose tissue. Hotamisligil et al. (65) were the first to describe adipose expression of TNF- $\alpha$ mRNA in different rodent models of obesity. Clinical studies have also revealed expression of TNF mRNA in human adipose tissue $(62,68,81)$. Subcutaneous fat depots exhibit a 1.67-fold higher TNF- $\alpha$ mRNA expression than omental fat depots (68). The amount of TNF- $\alpha$ mRNA is positively correlated with body adiposity and decreases in obese subjects after weight loss (112). TNF- $\alpha$ mRNA expression is also closely correlated with hyperinsulinemia, showing positive associations with fasting insulin and triglyceride concentrations (62).

Expression of TNF- $\alpha$ takes place already in adipocyte precursor cells, although the amount of specific mRNA increases only moderately in a differentiationdependent manner $(69,70)$. Interestingly, compounds that are used for the induction of adipose differentiation, such as the nonselective phosphodiesterase inhibitor IBMX and the thiazolidinediones, are inhibitors of TNF- $\alpha$ expression. In this sense, it is tempting to speculate that the adipogenic effect of these compounds may be at least partially mediated by a suppression of endogenous TNF- $\alpha$ production. Triglycerides and free fatty acids play an important role as physiological inducers of TNF- $\alpha$ expression. Feeding high-fat diets ( $45 \%$ of the energy content) is followed by a significant increase of TNF- $\alpha$ mRNA in fat pads of rats (113). Moreover, mice lacking the adipocyte fatty acid-binding protein aP2 do not express TNF- $\alpha$ in white adipose tissue (63), indicating that fatty acids are critically involved in the regulation of TNF- $\alpha$ expression in adipose tissue.

Expression pattern of TNF- $\alpha$ receptors. In addition to measuring TNF- $\alpha$ mRNA, it is also important to study the expression pattern of TNF receptors (TNFR) in adipose tissue. TNF- $\alpha$ interacts with two cell-surface receptors, p55 (p60 in humans) and p75 (p80 in humans) (52). Regulation of the expression of these two receptors seems to underlie separate mechanisms, because they present different cellular and tissue distribution patterns. The p60 TNFR appears to be primarily involved in insulin receptor signaling and glucose transport (121), and the p80 TNFR has been shown to be involved in the pathogenesis of TNF-induced insulin resistance $(61,96)$. The lack of p75 TNFR in dietinduced obese mice leads to body weight loss with improved insulin concentrations and sensitivity (142). Obese mice deficient in p55 TNFR showed slightly elevated insulin concentrations after 3 mo of a high-fat diet, whereas mice lacking both receptors were significantly hyperinsulinemic during the 4 mo of high-fat feeding (142). The researchers concluded that TNFR may be required for glucose homeostasis but do not exert a critical role in the development of insulin resistance. Conversely, the lack of p55 TNFR in $o b / o b$ mice has been shown to cause an improvement of insulin sensitivity, whereas a lack of the p75 TNFR alone did not alter insulin action but potentiated the effect of p55 TNFR deficiency in animals deficient in both receptors (168). Subsequent studies performed in preadipocyte cell lines from these knockout mice confirmed that TNF-induced insulin resistance, as well as alterations in the adipogenic program, can be attributed predominantly to the actions of the p55 TNFR (69).

The question arising is whether similar observations can be made in humans. Compared with lean controls, obese individuals with or without type 2 diabetes mellitus show significantly higher mRNA levels of both TNFR (68). The relative expression of p60 TNFR was strongly correlated with body mass index, whereas $\mathrm{p} 80$ TNFR mRNA varied widely in each group of subjects but was closely related to the amount of plasma triglycerides and, to some extent, was positively associated with the expression of its ligand. Apparently, selective activation of the p60 TNFR inhibited differentiation in human preadipocytes, whereas activation of the p80 TNFR resulted in increased differentiation (69). Inhibition of insulin-stimulated glucose transport in human cultured adipocytes was independently mediated by both receptors. However, published data are not always in agreement; some investigators have found a twofold increase in p80 TNFR mRNA levels in the obese state but no difference in p60 TNFR mRNA (61). These findings point to the possibility that both TNFR are involved in the development of TNF-induced insulin resistance through different mechanisms, although their exact interaction and relative contribution still remain to be completely disentangled.

The determination of circulating TNF- $\alpha$ and TNFR concentrations provides additional information regarding the role of the TNF system in human obesity. In contrast to the findings made in rodent models of obesity, where a marked increase in circulating TNF- $\alpha$ concentrations has been found (65), in obese diabetic and nondiabetic patients, $\mathrm{TNF}-\alpha$ concentrations are not substantially elevated $(55,123)$. The expression of TNF- $\alpha$ in human white adipose tissue is relatively low. Thus it remains doubtful whether adipose tissue is a major source of circulating TNF- $\alpha$ (68). This reasoning is also supported by an in vivo study measuring arteriovenous differences across a subcutaneous adipose tissue bed, which evidenced a nonsignificant contribution of white adipose tissue to the serum concentrations of TNF- $\alpha$ (110).

Disagreements regarding the serum concentrations of the proteolytically cleaved soluble TNFR in obese and insulin-resistant patients have also been obtained. Some researchers have shown $30-40 \%$ higher circulat- 
ing concentrations of both soluble receptor subtypes in obese compared with lean individuals (55), whereas another group has found sixfold concentrations of the soluble p80 TNFR in obese compared with lean subjects, but no differences in the circulating concentrations of the soluble p60 TNFR (61). The physiological relevance of these findings remains unknown. Both soluble receptor subtypes bind to $\mathrm{TNF}-\alpha$ in vitro and inhibit its biological activity by competing with cellsurface receptors for TNF- $\alpha$. Therefore, the release of soluble receptors may represent a mechanism of binding and inhibiting the TNF- $\alpha$ not immediately bound to surface receptors, thereby protecting other target cells and circumscribing its effect (173). It is conceivable that soluble receptors serve to neutralize circulating TNF- $\alpha$. The release of soluble receptors may imply a desensitizing mechanism of cells to the effects of TNF- $\alpha$. Conversely, low TNF- $\alpha$ concentrations, binding to soluble receptors, have been reported to stabilize TNF- $\alpha$ and increase its activity (69). Thus augmented concentrations of the soluble receptors may reflect either a state of receptor inactivation or an upregulated TNF system in obesity.

Biological effects of TNF- $\alpha$. TNF- $\alpha$ has pronounced catabolic effects in adipose tissue (69). It suppresses LPL at the mRNA and protein levels, as reported in many in vivo and in vitro studies. TNF- $\alpha$ inhibits the expression of the two master regulators of adipose differentiation, the transcription factor CCAAT/enhancer binding protein- $\alpha(\operatorname{CEBP} \alpha)$ and the nuclear receptor peroxisome proliferator-activated receptor- $\gamma 2$ (PPARy2) $(156,184)$. This suppression may result in the subsequent downregulation of many adipocyte-specific proteins, such as LPL, aP2, fatty acid synthetase, acetyl-CoA carboxylase, glycerol-3-phosphate dehydrogenase (GPDH), and GLUT-4 among others. Furthermore, mature adipocytes are stimulated to mobilize lipids upon TNF- $\alpha$ exposure, possibly via hormonesensitive lipase activation (56). Among the multiple properties of TNF- $\alpha$, the antiadipogenic effect is especially relevant, because adipose conversion of fat cell precursors is potently inhibited by TNF- $\alpha$ (122). Moreover, chronic treatment of mature fat cells with TNF- $\alpha$ has been shown to lead to a reversion of the adipocyte phenotype back to a fibroblast-like morphology (122).

Although it was formerly assumed that TNF- $\alpha$ selectively mediates apoptosis in tumor cells, it has been suggested that this could also be of relevance for human preadipocytes and adipocytes (128). Programmed cell death could represent another mechanism by which TNF- $\alpha$ can modulate adipose tissue cellularity. Thus TNF- $\alpha$ could decrease adipose tissue mass by reducing not only fat cell volume but also adipocyte number.

Adipose tissue expansion may occur by adipocyte hypertrophy, hyperplasia, or both $(14,60)$. Fat cells reaching a critical size trigger the events that result in proliferation of adipocytes. An increase in fat cell size before the onset of adipocyte hyperplasia has been observed in diet-induced obese rats (47). Adipose tissue levels of TNF- $\alpha$ and IGF-I have been shown to be higher in both human and rodent obesity $(45,87,105)$, but these paracrine factors have seemingly opposing effects on adipose tissue development. IGF-I induces both mitogenic and differentiation responses in preadipocyte cultures (178), whereas TNF- $\alpha$ inhibits the expression of adipogenic enzymes (184). It can be hypothesized that TNF- $\alpha$ may exert a permissive role in adipose tissue expansion, whereby its production increases when existing fat cells reach a critical size. Because TNF- $\alpha$ is a very potent inhibitor of differentiation, it may act to drive cells into a mitogenic program directly or by other mechanisms such as increasing growth factor responsiveness. Recently, it has been shown that IGF-I, produced in response to enlarging fat cells, acts synergistically with TNF- $\alpha$ to further enhance proliferation (89). The net result from this interaction would be an increase of the stromal-vascular or uncommitted cell pool whereby these cells might then be recruited to become adipocytes or might alternatively serve as infrastructure to support adipose tissue growth. Furthermore, it has been suggested that loss of the ability of IGF-I to activate Shc signaling to mitogen-activated protein kinase (MAPK) may be an early component of adipogenesis (13).

\section{Leptin}

A major development in energy balance regulation has come with the discovery in 1994 of leptin, the protein product of the $o b$ gene (196). The initial concept was that leptin informs the brain about the abundance of body fat, thereby allowing feeding behavior, metabolism, and endocrine physiology to be coupled to the nutritional state of the organism $(1,44)$. Leptin consists of four antiparallel $\alpha$-helices, connected by two long crossover links and one short loop, arranged in a left-hand twisted helical bundle. The interhelical angles and features of the long crossover loops are similar to those found in the long-chain helical cytokine crystal structures, which include granulocyte colony-stimulating factor (GSCF), LIF, ciliary neurotropic factor (CNTF), and human GH $(101,193)$.

Leptin expression in adipose tissue. Leptin biosynthesis and release are governed by paracrine, endocrine, and neuroendocrine signals that impinge on the adipocyte $(1,44,111,166)$. Because leptin is secreted by fat cells in proportion to body fat stores, it has the potential to play a key regulatory role in fuel homeostasis (166). As would be predicted of a factor involved in energy balance, expression of the $o b$ gene is subject to nutritional regulation. Fasting induces a fall in the level of $o b$ mRNA, which is rapidly reversed on refeeding, and circulating leptin levels change in parallel with tissue mRNA $(44,166)$. Glucosamine infusion increases leptin expression in adipose tissue and induces de novo leptin synthesis in rat skeletal muscle (179). Glucose infusion and lipid infusion have similar effects on leptin expression in adipose tissue and muscle, raising the possibility that leptin acts as a sensor of nutrient flux in these tissues. 
Evidence for a direct autocrine/paracrine effect of leptin on the lipolytic activity of isolated adipocytes has recently been reported (43). In addition, leptin has been shown to repress acetyl-CoA carboxylase gene expression, fatty acid synthesis, and lipid synthesis; these are biochemical reactions that contribute to lipid accumulation without the participation of centrally mediated pathways (145, 180, 181). Thus leptin is involved in the direct regulation of adipose tissue metabolism by both inhibiting lipogenesis and stimulating lipolysis (44). Insulin stimulates $o b$ gene expression, as do estrogens and glucocorticoids, with the effects of the latter being maintained during chronic treatment. Although plasma leptin, thyroid-stimulating hormone (TSH), and adiposity correlate in euthyroid patients, there are conflicting reports on the effect of hypo- and hyperthyroidism on $o b$ gene expression (1). Androgens and GH decrease ob gene expression (1, $6,44)$. Similarly, cold exposure induces a sympathetically mediated suppression of the $o b$ gene, leading to a rapid decrease in both $o b$ mRNA and serum leptin concentrations (166).

Plasma leptin concentrations and adipocyte $o b$ mRNA expression are strongly correlated with estimates of obesity, and total fat mass, percent body fat, and body mass index are the best predictors (1). Leptin mRNA shows higher expression in subcutaneous than in omental adipocytes (112). In addition, a striking sexual dimorphism is evident in both ob mRNA expression and circulating leptin concentrations, with almost twofold higher leptin concentrations in women (44). Adipocyte size is an important determinant of leptin synthesis, because larger fat cells contain more leptin than smaller adipocytes from the same individual $(1,23)$. However, it is not known whether increased triglyceride contents, lipid metabolites, or mechanical factors associated with augmented adipocyte size influence leptin expression. It has been shown that a proportional increase in adipocyte size is insufficient to explain the sex- and site-specific differences observed (112). Omental fat depots represent a more rapidly mobilizable source of energy in the form of free fatty acids, particularly in response to stress hormones. Thus the observation of increased leptin mRNA in subcutaneous compared with omental adipocytes may imply that omental adipose tissue is a less important contributor to the long-term feedback loop controlling appetite and metabolic rate than subcutaneous adipose tissue. Although this property of omental fat may be advantageous in allowing a more efficient use of available calories in times of alternating food scarcity and plenty, in modern sedentary humans with an ensured food supply, reduced leptin mRNA expression, and hence leptin production from omental adipocytes, may contribute to the high prevalence of central obesity with its associated pathological consequences. Some researchers attribute the observed gender differences to the stimulating role of estrogens and the suppressive effect of circulating androgens, but other investigators have not been able to ascribe the sexual dimorphism to sex hormones $(44,103)$. Further studies will be required to address the molecular basis for and physiological consequences of depot- and sex-specific variation in $o b$ mRNA expression in humans.

Cell-autonomous factors such as intracellular metabolites, signaling molecules, or transcription factors act as other major links between adipocyte size and leptin gene expression (151). Like many other adipocyte genes, the $o b$ gene promoter is positively regulated through a functional binding site for $\mathrm{CEBP} \alpha$ (6). In contrast, thiazoladinedione agonists for PPARy transcription factors suppress leptin expression (26). This may partly involve a functional antagonism between CEBP $\alpha$ and PPAR $\gamma$ on the leptin promoter, and this mechanism may explain the downregulation of leptin expression by thiazoladinediones $(1,6)$.

Furthermore, leptin production is influenced by immune activation. In this context, a positive and independent association between TNF- $\alpha$ and circulating leptin concentrations has been reported (104).

Leptin receptors. Consistent with leptin's pleiotropic effects, leptin receptors (OB-R) exhibit an almost universal distribution. The OB-R belong to the class I cytokine receptor family, which includes the receptors of IL-6, LIF, GSCF, and gp130 (1, 161). OB-R are produced in several alternatively spliced forms, designated OB-Ra, OB-Rb, OB-Rc, OB-Rd, and OB-Re. The receptors share an identical extracellular ligand-binding domain of 840 amino acids at the amino terminus, as well as a transmembrane domain of 34 amino acids, but they differ at the carboxy terminus. A variable intracellular domain, characteristic for each of the five receptor isoforms, has been identified. Only the fulllength isoform, the OB-Rb, is believed to be involved in leptin signaling and is considered to be the functional receptor. Recent reports have shown that activation of $\mathrm{OB}-\mathrm{Rb}$, and to a lesser extent OB-Ra, mediates ligandinduced activation of both JAK and STAT proteins $(1,8)$. The extracellular and cytoplasmic regions of OB-R and gp130 possess conserved motifs and are closely related to each other. OB-R and gp130 appear to mediate overlapping but distinct cytoplasmic signals (114). Furthermore, recent reports have shown that OB-R stimulate transcription via IL-6 and hematopoietin receptor-responsive elements (8). Thus OB-R share, at least in part, some of the signaling pathways characteristic of the class I cytokine receptor family. The lack of the full-length OB-R has been shown to be responsible for the $d b / d b$ mouse obesity phenotype and the fatty mutation $(8,161)$.

The OB-Re, which lacks the intracellular and transmembrane domains, circulates as a soluble receptor (93). Secreted extracellular domains of cytokine receptors are known to function as specific binding proteins (58). In mice, it has been observed that the putative soluble isoform, OB-Re, is produced at a level that is sufficiently high to act as a buffering system for free circulating leptin (97).

Biological effects of leptin. Leptin has diverse effects in addition to appetite and body weight regulation. Many cytokines, originally isolated on the basis of particular biological actions, have subsequently been 
shown to be capable of stimulating a variety of biological responses in a wide spectrum of cell types. Thus leptin shares with other cytokines an extreme functional pleiotropy and has been shown to be involved in quite diverse physiological functions, such as reproduction (17), hematopoiesis (20), angiogenesis (147), immune responsiveness (98), blood pressure control (42), and bone formation (30).

It has been shown that leptin is necessary for maturation of the reproductive axis, as evidenced by its ability to restore puberty and fertility in $o b / o b$ mice, accelerate puberty in wild-type mice, and facilitate reproductive behavior in rodents (1). Therefore, leptin signals the adequacy of energy stores for reproduction by interacting with different target organs in the hypothalamic-pituitary-gonadal axis (44).

The functional OB-R has been shown to be capable of signaling for cell survival, proliferation, and differentiation into macrophages $(20,46)$. In addition, leptin appears to be able to enhance the production of cytokines in macrophages and to increase the attachment and subsequent receptor-mediated process of phagocytosis (46). This activity may be mediated by an upregulation of macrophage receptors or by increased phagocytic activity. In this sense, a role for leukocyte adhesion receptors in maintenance of normal body weight and adiposity has recently been described (28). In addition, leptin has a direct proliferative effect on $\mathrm{T}$ cells, showing an adaptive response of this hormone to enhance the immune competence of the organism against the immunosuppression associated with starvation (98).

Leptin has to be included in the list of angiogenic factors secreted by adipose tissue, because it has been shown to cause cultured endothelial cells to aggregate, form tubes, and display a reticular array reminiscent of tissue vasculature (147). It has also been observed that leptin accelerates wound healing, a process depending on blood vessel growth.

Regarding blood pressure homeostasis, leptin appears to have a balanced effect, with a pressor response attributable to sympathetic activation and a depressor response attributable to NO release (42). Therefore, leptin is involved in the control of vascular tone by simultaneously producing a neurogenic pressor action and an opposing NO-mediated depressor effect. In this sense, leptin may be one of the factors underlying the association of obesity with increased incidence of hypertension and cardiovascular mortality.

A recent study identified leptin as a potent inhibitor of bone formation, acting through the central nervous system (30). Despite suffering from hypogonadism and hypercortisolism, known inducers of increased osteoclast number and bone resorption activity, leptin-deficient and OB-R-deficient mice exhibit a high bone mass phenotype. Interestingly, this phenotype is not secondary to obesity but is directly related to the lack of leptin signaling. Intracerebroventricular infusion of leptin to $o b / o b$ and wild-type mice was followed by a significant bone mass reduction (30).

\section{CROSS TALK AMONG ADIPOCYTE-DERIVED CYTOKINES}

TNF- $\alpha$, IL-6, and leptin share both structural and functional similarities with other cytokines, including receptor homology, signaling via the JAK/STAT system, growth factor properties, and circulation in plasma, either in the free form or bound to specific serum proteins $(7,8,44,101,161,193)$. All three cytokines are expressed and released by adipocytes, exerting a key role in fat mass control. TNF- $\alpha$ induces the release of both IL- 6 and leptin from adipose tissue $(54,138)$. Knockout mice for the TNF- $\alpha$ gene showed a hypoleptinemia compared with wild-type mice (85). Apparently, TNF- $\alpha$ induces leptin production through the p55 TNF receptor (36). All three cytokines, TNF- $\alpha$, IL-6, and leptin, are closely interrelated as well as influencing and being regulated by other hormones and the sympathetic nervous system (Fig. 4) (111, 124, 194).

Proinflammatory cytokines have been shown to play a major role in the initiation of the sepsis syndrome, with the amount and speed of their release correlating with the occurrence of septic shock and, eventually, with mortality (16). However, TNF- $\alpha$ and IL-1 are seldom found in the circulation of septic patients. It has been proposed that enhanced production of endogenous inhibitors of these cytokines, such as soluble TNFR and IL-1 receptor antagonist, as well as increased secretion of the anti-inflammatory cytokine IL-10, may be important host defense mechanisms to attenuate concurrent proinflammatory cytokine activity during sepsis. Leptin synthesis is stimulated by infection, endotoxin, and cytokines such as TNF- $\alpha$, LIF, and IL-1 $(54,74,138)$. The rise in leptin concentrations as a result of cytokine increase may contribute to the anorexia and weight loss accompanying these

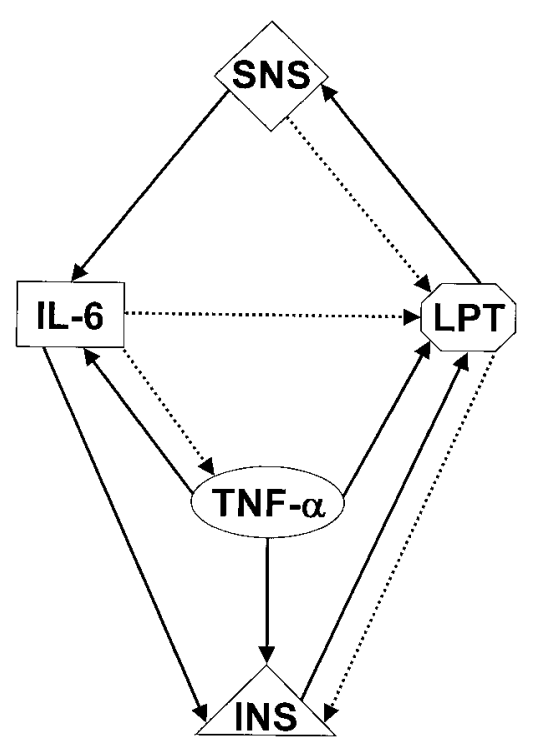

Fig. 4. Postulated cross talk between the main adipocyte-derived cytokines and interactions with sympathetic activity and insulin. Solid lines indicate stimulation; dashed lines indicate inhibition. SNS, sympathetic nervous system; LPT, leptin; INS, insulin. 
inflammatory conditions. An independent association for leptin with IL-1 receptor antagonist and IL-10 in sepsis and septic shock has been described (5). In addition, leptin and IL-6 have been shown to be independent predictors of death in both study groups. Because patients with sepsis and septic shock have higher plasma concentrations (2.3- and 4.2-fold, respectively) than those expected on the basis of their fat mass, it has been postulated that, in this case, circulating leptin does not signal the magnitude of energy stores to the hypothalamus but works rather as a stress-related peptide. Survivors of severe sepsis and septic shock exhibited leptin concentrations 1.3- and 1.6-fold greater than nonsurvivors in each group (5). Thus the leptin response may be related to the extent of activation of the immune system and may serve as a marker of the severity and outcome of septic patients (5), because leptin has been shown to stimulate proliferation of lymphohematopoetic cells and phagocytic activity of macrophages (46).

\section{CYTOKINES IN ENERGY REGULATION}

Although adipose tissue consumes little oxygen relative to other organs, it is an exceptionally efficient participant in the regulation of fuel selection in whole body physiology (38). Adipose tissue has the ability to regulate its metabolism, cell size, and cell number through the production of autocrine, paracrine, and endocrine signals. By participating in food intake regulation, the adipocyte literally controls the substrate flow available for storage of triglycerides.

Obesity results from both quantitative and qualitative changes at the adipose tissue level. An excess of adipose tissue frequently includes both hyperplasic and hypertrophic development $(14,22)$. This circumstance tends to exacerbate the overproduction of cyto- kines and other mediators, with the potential of exerting their effects both locally and systemically, and thus promoting the pathophysiological complications associated with increased fat mass (Fig. 5). As mentioned above, the efficiency of fat deposition is affected by local secretion of adipocyte-derived factors, which influence insulin signaling, decrease lipogenic gene expression, increase lipolysis, control blood flow, and regulate intracellular triglyceride synthesis. The mechanisms that lead to obesity are complex and involve multiple cytokines, hormones, and growth factors. The fact that TNF- $\alpha$, leptin, IL- 6 , insulin, PAI-1, TGF- $\beta$, and the like are elevated in obesity and induce other adipocytederived products in both plasma and adipose tissue reveals the participation of a highly intricate network of signals in the regulation of obesity. Undoubtedly, there are many other mechanisms and factors that regulate the level of energy stores by modulating the deposition and mobilization of adipose triglyceride pools and that need to be uncovered.

\section{EFFECTS OF CYTOKINES ON INSULIN SIGNALING}

There is growing experimental evidence from animal studies that $\mathrm{TNF}-\alpha$ plays a key role in the pathogenesis of insulin resistance associated with obesity (69). Hotamisligil et al. (65) were the first to report a close relationship between increased adipose TNF- $\alpha$ expression and features of insulin resistance in rodent models of obesity and type 2 diabetes mellitus (65). In obese fa/fa rats, insulin resistance could be reversed by infusion of a TNF- $\alpha$-neutralizing IgG fusion protein containing soluble TNFR domains. Subsequent investigations showed that TNF- $\alpha$ interferes with the tyrosine phosphorylation of the insulin receptor in Fao hepatocytes and 3T3 cells (35). Further experiments demonstrated that TNF- $\alpha$ induces phosphorylation of insulin

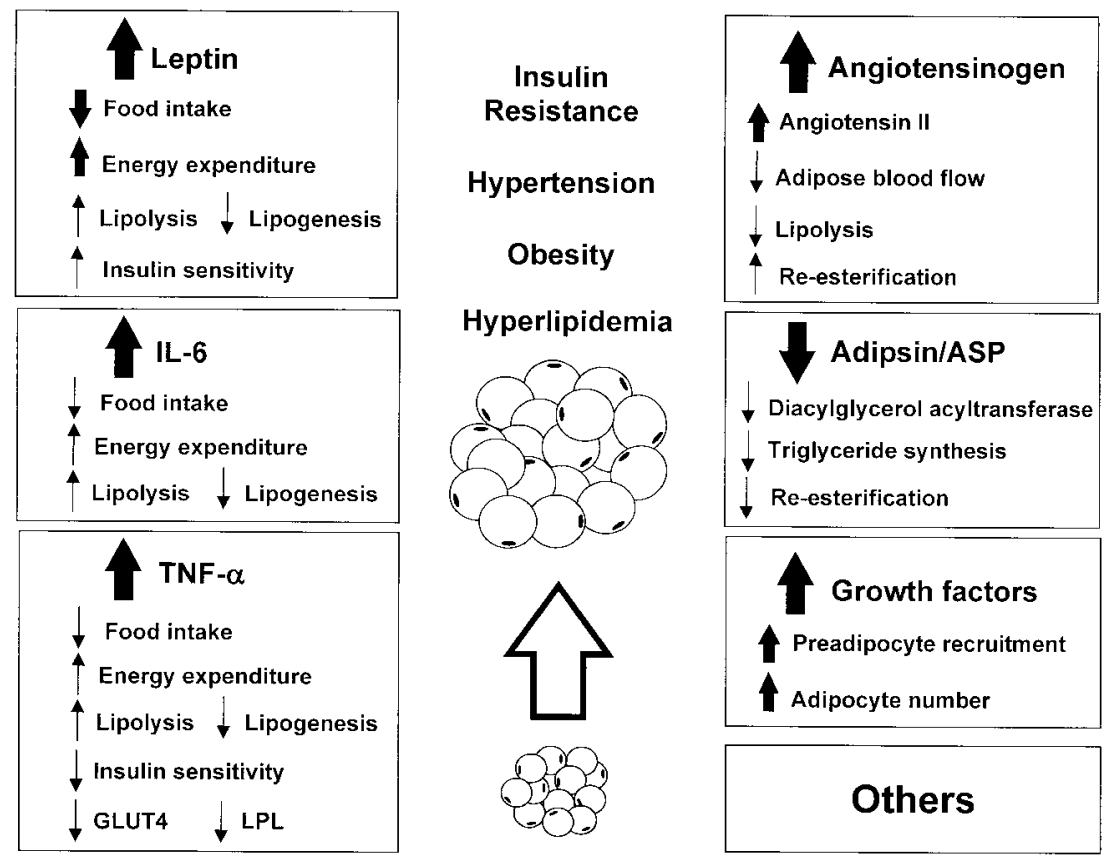

Fig. 5. Overproduction of adipocyte-derived factors and associated pathophysiological complications. LPL, lipoprotein lipase. 
receptor substrate-1 (IRS-1) at serine residues and that serine-phosphorylated IRS-1 operates as an inhibitor of insulin receptor activity $(64,80)$. By use of a fibroblast cell line overexpressing the human insulin receptor, a role for phosphotyrosine phosphatases in the TNF-mediated inhibition of insulin signaling has been postulated (90). Furthermore, in response to acute insulin stimulation after cellular TNF- $\alpha$ exposure, a normal tyrosine phosphorylation of the insulin receptor and IRS-1, together with a reduced expression of proteins involved in insulin action, such as IRS-1 and GLUT-4, has been reported, representing a plausible explanation for the observed insulin resistance of glucose transport (155). The potential role of IRS-2 in TNF-induced insulin resistance has yielded conflicting results. Although in hepatoma cells and brown adipocytes IRS-2 has been shown to be involved in the induction of insulin resistance through TNF- $\alpha$ (120), in cultured white fat cells, IRS-2 did not mediate the inhibition of insulin signaling by TNF- $\alpha$ (121).

So far, most studies on the mechanisms of insulin resistance related to $\mathrm{TNF}-\alpha$ have been carried out in animal models. However, whether this holds true for humans has not been completely elucidated. A rapid inhibition of insulin signaling at the phosphatidylinositol (PI) 3-kinase level by TNF- $\alpha$ treatment and a concomitant inhibition of insulin-stimulated glucose transport in isolated human adipocytes have been reported $(69,96)$. The effect of TNF- $\alpha$ was correlated with an inhibition of tyrosine phosphorylation of IRS-1 with unaltered autophosphorylation of the insulin receptor $\beta$-subunit (Fig. 6). Long-term exposure to TNF- $\alpha$ in vitro of differentiated human adipocytes resulted in a dramatic reduction of GLUT-4, whereas GLUT-1 expression was upregulated (56). On the contrary, intravenous administration of a recombinant-engineered human TNF-neutralizing antibody to patients with type 2 diabetes mellitus did not alter fasting glucose and insulin concentrations. Furthermore, glucose clearance during intravenous insulin sensitivity tests remained unaffected by the TNF-neutralizing antibody treatment, arguing against a prominent role of circulating TNF in the development of insulin resistance in humans (118).

Although the mechanisms of TNF-mediated insulin resistance are only incompletely understood, TNF- $\alpha$ is a potentially attractive target for pharmacological intervention aimed at protecting against obesity-induced insulin resistance $(124,169)$. Numerous strategies are currently in progress in controlled clinical trials to suppress the production or activity of TNF- $\alpha$ in a variety of diseases (33). It will be interesting to establish whether suppression of TNF- $\alpha$ improves insulin sensitivity in humans and how it influences adipose tissue metabolism.

Ligand binding to the OB-Rb results in the activation of JAK2 by transphosphorylation and the subsequent tyrosine phosphorylation of tyrosine residues on the intracellular OB-Rb $(7,11)$. In general, tyrosine phosphorylation of cytokine and growth factor receptors activates intracellular signals by recruiting specific signaling proteins with specialized phosphotyrosine-binding domains called SH2 domains. Thus the two OB-Rb tyrosine residues that are phosphorylated during receptor activation mediate distinct signaling pathways, with SHP-2 binding to Tyr 985 positively

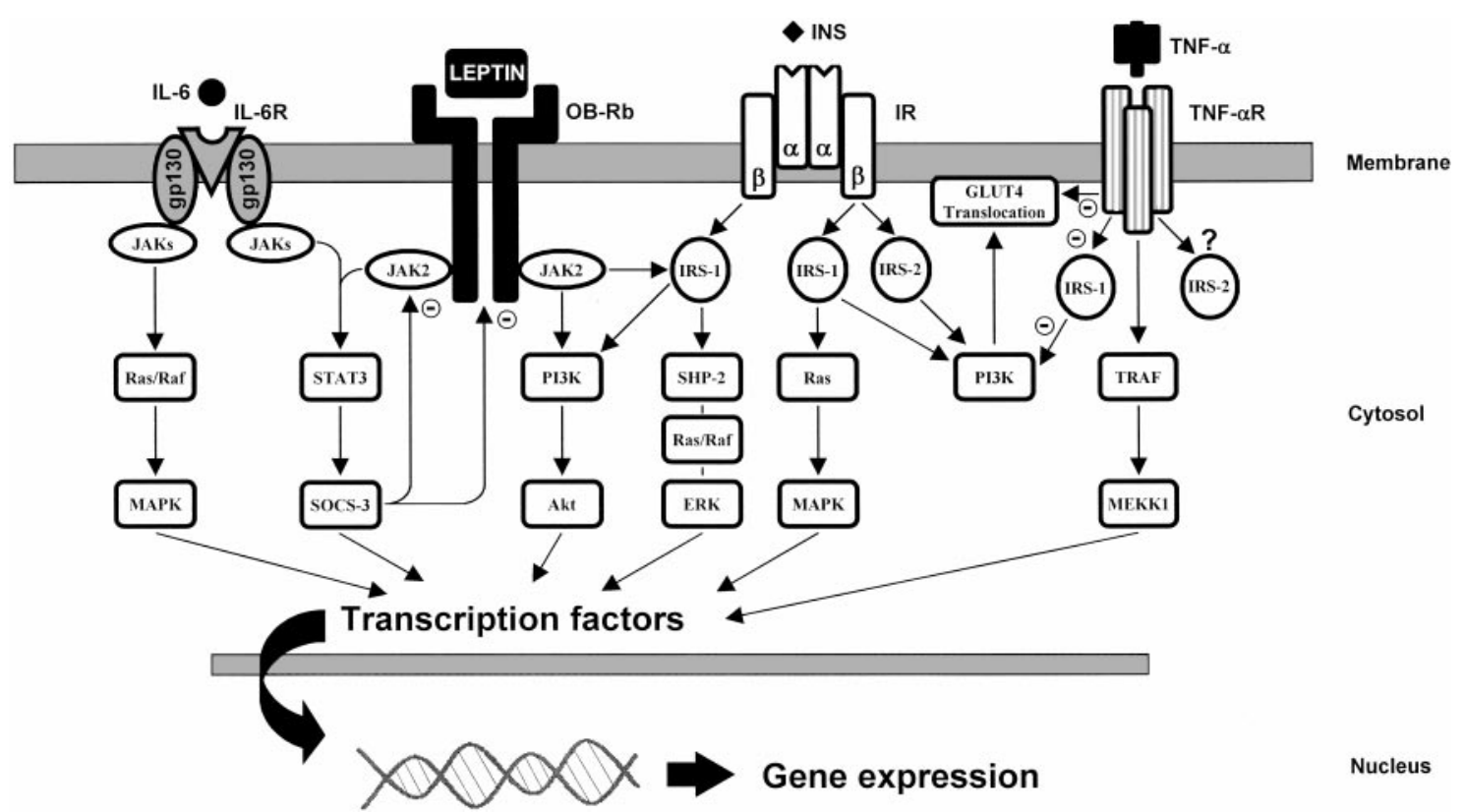

Fig. 6. Schematic representation of the signaling pathways of IL-6, leptin, and TNF- $\alpha$ and their interaction with insulin signaling. JAK, Janus kinases; STAT, signal transducers and activators of transcription; SOCS-3, suppressor of cytokine signaling-3; MAPK, mitogen-activated protein kinases; IR, insulin receptor; IRS, insulin receptor substrates; PI3K, phosphatidylinositol 3-kinase; Akt, protein kinase B; ERK, extracellular factorregulated kinases; TRAF, TNF receptor-associated factor; MEKK1, MAP/ERK kinase kinase-1. 
regulating the extracellular factor-regulated kinase (ERK)-c-fos pathway, and STAT3 binding to $\mathrm{Tyr}^{1138}$ mediating the inhibitory SOCS-3 pathway $(7,10,11$, 94). It has been shown that SOCS-3 is a leptin-regulated inhibitor of proximal leptin signaling in vivo, and, therefore, excessive SOCS-3 activity in leptin-responsive cells is a potential mechanism for leptin resistance (94).

Leptin is not only a central regulator of body fat mass by decreasing food intake and increasing energy expenditure, but it also could be involved in insulin resistance induction, possibly via peripheral mechanisms of action (44). Recent reports suggest complex interactions between the leptin and insulin signaling pathways that can potentially lead to differential modification of the metabolic effects of insulin exerted through insulin receptor substrates (IRS-1 and IRS-2). In fact, leptin can act through some components of the insulin-signaling cascade, such as IRS-1 and IRS-2, PI 3-kinase, and MAPK, and can modify insulin-induced changes in gene expression in vitro and in vivo (84, 159). It has been shown that, in Fao cells, leptin alone has no effect on the insulin-signaling pathway, but leptin pretreatment transiently enhances insulin-induced tyrosine phosphorylation and PI 3-kinase binding to IRS-1 while producing an inhibition of tyrosine phosphorylation and PI 3-kinase binding to IRS-2 (159). Leptin alone also induces serine phosphorylation of Akt and glycogen synthase 3, but to a lesser extent than insulin, and the combination of these hormones is not additive. A divergence of leptin effects on insulinstimulated IRS-1 and IRS-2-mediated signaling and on three downstream kinases suggests a complex and multidimensional interaction between these two hormonal signaling systems. Leptin rapidly activates signaling pathways directly at the level of insulin-sensitive tissues through the OB-Rb, and these pathways overlap with, but are distinct from, those engaged by insulin (84).

TNF- $\alpha$ has been shown to induce a rapid release of leptin from white adipose tissue $(54,85)$. Human studies have yielded conflicting results. Infusion of TNF- $\alpha$ to patients was followed by a rapid rise in serum leptin concentrations (198), whereas long-term exposure of cultured human adipocytes to $\mathrm{TNF}-\alpha$ resulted in a reduction of leptin mRNA levels (50). Therefore, further studies are needed to clarify the exact relationship between TNF- $\alpha$ and leptin in the context of insulin resistance.

It has recently been shown that, in the presence of markedly reduced insulin action in skeletal muscle, glucose is partly shunted to white adipose tissue (83). Thus selective insulin resistance in muscle promotes redistribution of substrates to adipose tissue, thereby contributing to increased adiposity and development of the prediabetic syndrome. In obese patients, increased production of nonesterified fatty acids and cytokines contributes to insulin resistance. The changes in systemic metabolism that lead to insulin resistance have been reported to develop in an attempt to prevent further weight gain (32). Mobilization of energy stores, impaired insulin signaling, increased lipolysis, and central neuroendocrine effects, such as HPA activation, may be adaptive under certain circumstances, including the early stages of fuel storage and in acute inflammation, whereas such changes may become maladaptive during sustained weight gain (111). In this sense, IL-6 reduces LPL activity, reducing fuel storage and thereby limiting weight gain on the one hand, but IL-6 also increases hepatic synthesis of procoagulant molecules, contributing to dyslipidemia on the other hand.

The receptor complex mediating the biological activities of IL-6 consists of two distinct membrane-bound glycoproteins, an $80-\mathrm{kDa}$ cognate receptor (IL-6R) and a $130-\mathrm{kDa}$ signal-transducing element (gp130). Cellular activation by IL- 6 requires binding to its cognate receptor and the resulting dimerization of gp130 (77). In addition to the membrane-bound receptor, the IL-6Rs binds IL-6 with a similar affinity to that of the cognate receptor and prolongs its plasma half-life. The IL-6R/IL-6Rs complex is capable of activating cells via interaction with membrane-bound gp130 (Fig. 6). This feature makes the IL-6R/IL-6Rs complex an agonist for cell types that, although they express gp130, would not inherently respond to IL-6 alone (77). Hence, the IL-6Rs has the ability to widen the repertoire of cell types that are responsive to IL-6. Signaling is facilitated through the homodimerization of gp130 to the ligand-receptor complex. This mediates phosphorylation of gp130-associated JAKs, which facilitates the docking of STAT1/STAT3 factors to gp130 and their phosphorylation. IL-6 also activates the Ras-Raf signaling cascade, which regulates phosphorylation of MAPK and ultimately activation of transcription factors such as CEBP (77).

\section{CROSS TALK WITH NEUROENDOCRINE PATHWAYS}

Adipose tissue is an endocrine organ influencing many aspects of fuel metabolism through a network of local and systemic signals that interact with the established neuroendocrine regulators. Cytokine production appears to be acutely regulated by sympathetic stimulation. Catecholamines have been shown to regulate the production of leptin, IL-6, and TNF- $\alpha$ (111). Isoprenaline infusions in humans had a stimulatory effect on circulating IL-6 concentrations, but little or no appreciable change was observed in TNF- $\alpha$. Conversely, catecholamines and synthetic adrenergic agonists have been demonstrated to rapidly suppress leptin mRNA levels in mouse adipocytes (166), whereas in humans, isoprenaline produced an acute suppression of plasma leptin concurrently with an increased lipolytic activity (125).

It has been reported that IL-6 directly stimulates adrenal cortisol release in addition to stimulating hypothalamic $\mathrm{CRH}$ and pituitary ACTH release (72). Adipose tissue IL-6 may, therefore, act as a feedforward regulator of HPA function. Cortisol suppression of adipose IL-6 production may serve as a feedback inhibitor of this regulatory loop. Adrenal cortisol production 
could be influenced by IL- 6 originating from perirenal adipose tissue surrounding the adrenal gland itself. In humans, IL-6 administration has been shown to induce a synchronized dose-dependent increase in resting metabolic rate and HPA activity, suggesting that hypothalamic $\mathrm{CRH}$ may mediate both of these functions (167). In contrast to stimulating ACTH, cortisol, GH, and prolactin release, IL-6 suppresses TSH secretion in a dose-dependent manner. This finding provides support to the participation of IL-6 and other inflammatory cytokines in generating the "euthyroid sick syndrome" in acute illness (92). The acute effects of IL-6 on GH, prolactin, and TSH release are also thought to be mediated via actions on hypothalamic control centers (108). Direct actions of IL-6 to modify anterior pituitary hormone release are plausible but unlikely, because they usually take more than $4-8 \mathrm{~h}$ to appear, and they have been documented to begin after $1 \mathrm{~h}$ of peaking between 3 and $4 \mathrm{~h}$ (167). Moreover, how circulating IL-6 reaches hypothalamic CRH and other regulatory neurons remains unclear, given the existence of the protective blood-brain barrier. There may be a special transport system for inflammatory cytokines, or they may directly activate the terminals of these neurons on the median eminence, which is outside the blood-brain barrier. Alternatively, IL-6 may cause endothelial and glial cells to secrete other mediators of inflammation, which reach the hypothalamic neurons in a cascade-like fashion (126).

Interestingly, no appreciable changes in luteinizing hormone (LH) and follicle-stimulating hormone release in response to IL-6 administration have been observed (167). This is in agreement with animal studies (108) but contrasts with the inhibitory effects of IL-1 and TNF- $\alpha$ on the pulsatile release of LH (130).

The studies looking at the relation between plasma leptin and cortisol concentrations have yielded conflicting results (111). Diurnal variations of leptin and cortisol are inversely related, with leptin concentrations peaking during the nadir of cortisol secretion (95). Furthermore, physiological doses of leptin have been shown to inhibit ACTH-stimulated cortisol production in cultured cells (15). Leptin increases CRH expression in the paraventricular nucleus. Thus leptin and the HPA axis are reciprocally related, with interactions at several levels. Glucocorticoids have been suggested to exert a counterregulatory influence on leptin action, with the HPA axis activity possibly setting a level of target-organ sensitivity to leptin (190).

\section{CONCLUDING REMARKS}

Adipocyte triglyceride stores are continously turning over at a rate that is tightly controlled by hormones. The physiological, cellular, and molecular mechanisms regulating the primary function of fat cells, to store excess ingested energy as triglycerides and to release fatty acids to meet the energy needs of other tissues, have been rapidly unfolding in the past decades. Novel metabolic functions of adipose tissue, apart from its central role in triglyceride metabolism, have been un- covered. In addition to the classical actions of insulin and counterregulatory hormones on adipocyte metabolism, fat cells play an active role in modulating their own metabolism, and hence their size, via autocrine and paracrine mechanisms. Newly discovered roles include the production of the cytokines IL-6, TNF- $\alpha$, and leptin, which play decisive roles in the development of obesity and insulin resistance. The local production of angiotensinogen may play an etiological role in the development of obesity-related hypertension. Furthermore, synthesis of estrogens by adipose tissue may mediate effects of obesity on the risk for osteoporosis and cancer. Thus the enlargement of the adipose mass has pleiotropic effects on endocrine and metabolic events at the whole body level that may contribute to the pathogenesis of detrimental complications of obesity.

\section{REFERENCES}

1. Ahima RS and Flier JS. Leptin. Annu Rev Physiol 62: 413$437,2000$.

2. Ailhaud $\mathbf{G}$ and Hauner $\mathbf{H}$. Development of white adipose tissue. In: Handbook of Obesity (1st ed.), edited by Bray GA, Bouchard C, and James WPT. New York: Dekker, 1998, p. 359-378.

3. Andersson K, Gaudiot N, Ribière C, Elizalde M, Giudicelli $\mathbf{Y}$, and Arner P. A nitric oxide-mediated mechanism regulates lipolysis in human adipose tissue in vivo. $\mathrm{Br} J$ Pharmacol 126: 1639-1645, 1999.

4. Armellini F, Zamboni M, and Bosello O. Hormones and body composition in humans: clinical studies. Int $J$ Obes 24, Suppl 2: S18-S21, 2000.

5. Arnalich F, López J, Codoceo R, Jiménez M, Madero R, and Montiel C. Relationship of plasma leptin to plasma cytokines and human survival in sepsis and septic shock. $J$ Infect Dis 180: 908-911, 1999.

6. Baile CA, Della-Fera MA, and Martin RJ. Regulation of metabolism and body fat mass by leptin. Annu Rev Nutr 20: 105-127, 2000.

7. Banks AS, Davis SM, Bates SH, and Myers MG Jr. Activation of downstream signals by the long form of the leptin receptor. J Biol Chem 275: 14563-14572, 2000.

8. Baumann H, Morella KK, White DW, Dembski M, Bailon PS, Kim H, Lai CF, and Tartaglia LA. The full-length leptin receptor has signaling capabilities of interleukin 6-type cytokine receptors. Proc Natl Acad Sci USA 93: 8374-8378, 1996.

9. Birgel M, Gottschling-Zeller H, Röhrig K, and Hauner H. Role of cytokines in the regulation of plasminogen activator inhibitor-1 expression and secretion in newly differentiated subcutaneous human adipocytes. Arterioscler Thromb Vasc Biol 20: 1682-1687, 2000.

10. Bjørbæk C, El-Haschimi K, Frantz JD, and Flier JS. The role of SOCS-3 in leptin signaling and leptin resistance. $J$ Biol Chem 264: 30059-30065, 1999.

11. Bjørbæk C, Uotani S, da Silva B, and Flier JS. Divergent signaling capacities of the long and short isoforms of the leptin receptor. J Biol Chem 272: 32686-32695, 1997.

12. Björntorp $\mathbf{P}$. The regulation of adipose tissue distribution in humans. Int J Obes 20: 291-302, 1996.

13. Boney CM, Gruppuso PA, Faris RA, and Frackelton AR Jr. The critical role of Shc in insulin-like growth factor-Imediated mitogenesis and differentiation in 3T3-L1 preadipocytes. Mol Endocrinol 14: 805-813, 2000.

14. Boone C, Mourot J, Grégoire F, and Remacle C. The adipose conversion process: regulation by extracellular and intracellular factors. Reprod Nutr Dev 40: 325-358, 2000.

15. Bornstein SR, Uhlmann KI, Haidan A, Ehrhart-Bornstein M, and Scherbaum WA. Evidence for a novel peripheral action of leptin as a metabolic signal to the adrenal gland: 
leptin inhibits cortisol release directly. Diabetes 46: 1235-1238, 1997.

16. Casey L, Blak RA, and Bone RC. Plasma cytokine and endotoxin levels correlate with survival in patients with sepsis. Ann Intern Med 119: 771-778, 1993.

17. Chehab FF, Lim ME, and Lu RH. Correction of the sterility defect in homozygous obese female mice by treatment with the human recombinant leptin. Nature Genet 12: 318-320, 1996.

18. Chen NX, Hausman GJ, and Wright JT. Influence of thyroxine in vivo on preadipocyte development and insulin-like growth factor-I and IGF binding protein secretion in fetal stromal vascular cell cultures. Obes Res 4: 357-366, 1996.

19. Choy L, Rosen B, and Spiegelman BM. Adipsin and an endogenous pathway of complement from adipose cells. $J$ Biol Chem 267: 12736-12741, 1992.

20. Cioffi JA, Shafer AW, Zupancic TJ, Smith-Gbur J, Mikhail A, Platika D, and Snodgrass HR. Novel B219/OB receptor isoforms: possible role of leptin in hematopoiesis and reproduction. Nature Med 2: 585-589, 1996.

21. Cook KS, Groves DL, Min HY, and Spiegelman BM. A developmentally regulated mRNA from $3 \mathrm{~T} 3$ adipocytes encodes a novel serine protease homologue. Proc Natl Acad Sci USA 82: 6480-6484, 1986.

22. Cornelius P, MacDougald OA, and Lane MD. Regulation of adipocyte development. Annu Rev Nutr 14: 99-129, 1994.

23. Couillard $\mathbf{C}$, Mauriège $\mathbf{P}$, Imbeault $\mathbf{P}$, Prud'homme $\mathbf{D}$, Nadeau A, Tremblay A, Bouchard C, and Després JP. Hyperleptinemia is more closely associated with adipose cell hypertrophy than with adipose tissue hyperplasia. Int $J$ Obes 24: 782-788, 2000 .

24. Darimont C, Vassaux G, Ailhaud G, and Negrel R. Differentiation of preadipose cells: paracrine role of prostacyclin upon stimulation of adipose cells by angiotensin-II. Endocrinology 135: 2030-2036, 1994.

25. De Mitrio V, De Pergola G, Vettor R, Marino R, Sciaraffia M, Pagano C, Scaraggi FA, Di Lorenzo L, and Giorgino $R$. Plasma plasminogen activator inhibitor-1 is associated with plasma leptin irrespective of body mass index, body fat mass, and plasma insulin and metabolic parameters in premenopausal women. Metabolism 48: 960-964, 1999.

26. De Vos P, Lefebvre AM, Miller SG, Guerre-Millo M, Wong K, Saladin R, Hamann LG, Staels B, Briggs MR, and Auwerx J. Thiazolidinediones repress ob gene expression in rodents via activation of peroxisome proliferator-activated receptor $\gamma$. J Clin Invest 98: 1004-1009, 1996.

27. Dieudonne MN, Pecquery R, Leneveu MC, and Giudicelli Y. Opposite effects of androgens and estrogens on adipogenesis in rat preadipocytes: evidence for sex- and site-related specificities and possible involvement of insulin-like growth factor 1 receptor and peroxisome proliferator-activated receptor gamma2. Endocrinology 141: 649-656, 2000.

28. Dong ZM, Gutierrez-Ramos JC, Coxon A, Mayadas TN, and Wagner DD. A new class of obesity genes encodes leukocyte adhesion receptors. Proc Natl Acad Sci USA 94: 75267530, 1997.

29. Drucker DJ. Glucagon-like peptides. Diabetes 47: 159-169, 1998.

30. Ducy $\mathbf{P}$, Amling M, Takeda S, Priemel M, Schilling AF, Beil FT, Shen J, Vinson C, Rueger JM, and Karsenty G. Leptin inhibits bone formation through a hypothalamic relay: a central control of bone mass. Cell 100: 195-207, 2000.

31. Dyer CJ, Simmons JM, Matteri RL, and Keisler DH. Effects of an intravenous injection of NPY on leptin and NPY-Y1 receptor mRNA expression in ovine adipose tissue. Domest Anim Endocrinol 14: 325-333, 1997.

32. Eckel RH. Insulin resistance: an adaptation for weight maintenance. Lancet 340: 1452-1453, 1992.

33. Eigler A, Sinha B, Hartmann G, and Enders S. Taming TNF: strategies to restrain this proinflammatory cytokine. Immunol Today 18: 487-492, 1997.

34. Endo T, Ohta K, Haraguchi K, and Onaya T. Cloning and functional expression of a thyrotropin receptor $\mathrm{cDNA}$ from rat fat cells. J Biol Chem 270: 10833-10837, 1995.
35. Feinstein R, Kanety H, Papa MZ, Lunenfeld B, and Karasik A. Tumor necrosis factor alpha suppresses insulininduced tyrosine phosphorylation of insulin receptor and its substrates. J Biol Chem 268: 26055-26058, 1993.

36. Finck BN and Johnson RW. Tumor necrosis factor (TNF)- $\alpha$ induces leptin production through the p55 TNF receptor. Am $J$ Physiol Regulatory Integrative Comp Physiol 278: R537-R543, 2000.

37. Flier JS. The adipocyte: storage depot or node on the energy information superhighway? Cell 80: 15-18, 1995.

38. Frayn KN, Humphreys SM, and Coppack SW. Fuel selection in white adipose tissue. Proc Nutr Soc 54: 177-189, 1995.

39. Frayn KN, Shadid S, Hamlani R, Humphreys SM, Clark ML, Fielding BA, Boland O, and Coppack SW. Regulation of fatty acid movement in human adipose tissue in the postabsorptive-to-postprandial transition. Am J Physiol Endocrinol Metab 266: E308-E317, 1994.

40. Fried SK, Bunkin DA, and Greenberg AS. Omental and subcutaneous adipose tissues of obese subjects release interleukin-6: depot difference and regulation by glucocorticoid. $J$ Clin Endocrinol Metab 83: 847-850, 1998.

41. Fried SK and Russell CD. Diverse roles of adipose tissue in the regulation of systemic metabolism and energy balance. In: Handbook of Obesity (1st ed.), edited by Bray GA, Bouchard C, and James WPT. New York: Dekker, 1998, p. 397-413.

42. Frühbeck G. Pivotal role of nitric oxide in the control of blood pressure following leptin administration. Diabetes 48: 903-908, 1999.

43. Frühbeck G, Aguado M, and Martínez JA. In vitro lipolytic effect of leptin on mouse adipocytes: evidence for a possible autocrine/paracrine role of leptin. Biochem Biophys Res Commun 240: 590-594, 1997.

44. Frühbeck G, Jebb SA, and Prentice AM. Leptin: physiology and pathophysiology. Clin Physiol 18: 399-419, 1998.

45. Frystyk J, Vestbo E, Skjaerbaek C, Mogensen CE, and Orskov H. Free insulin-like growth factors in human obesity. Metabolism 44: 37-44, 1995

46. Gainsford T, Willson TA, Metcalf D, Handman E, McFarlane C, Ng A, Nicola NA, Alexander WS, and Hilton DJ. Leptin can induce proliferation, differentiation, and functional activation of hemopoietic cells. Proc Natl Acad Sci USA 93: 14564-14568, 1996.

47. Gale SK, Van Itallie TB, and Faust IM. Effects of palatable diets on body weight and adipose tissue cellularity in the adult obese female Zucker rat (fa/fa). Metabolism 30: 105-110, 1981.

48. Gaudiot N, Jaubert AM, Charbonnier E, Sabourault D, Lacasa D, Giudicelli Y, and Ribière C. Modulation of white adipose tissue lipolysis by nitric oxide. J Biol Chem 273: 1347513481, 1998.

49. Germinario R, Sniderman AD, Manuel S, Lefebvre SP, Baldo A, and Cianflore K. Coordinating regulation of triacylglycerol synthesis and glucose transport by acylation stimulating protein. Metabolism 42: 574-580, 1993.

50. Gottschling-Zeller H, Birgel M, Scriba D, Blum WF, and Hauner H. Depot-specific release of leptin from subcutaneous and omental adipocytes in suspension culture: effect of tumor necrosis factor- $\alpha$ and transforming growth factor- $\beta 1$. Eur $J$ Endocrinol 141: 436-442, 1999.

51. Greenberg AS, Nordan RP, McIntosh J, Calvo JP, Scow RO, and Jablons D. Interleukin 6 reduces lipoprotein lipase activity in adipose tissue of mice in vivo and in 3T3-L1 adipocytes: a possible role for interleukin 6 in cancer cachexia. Cancer Res 52: 4113-4116, 1992.

52. Grell M. Tumor necrosis factor (TNF) receptors in cellular signaling of soluble and membrane-expressed TNF. J Inflamm 47: 8-17, 1995-96.

53. Grunfeld $\mathbf{C}$ and Feingold KR. The metabolic effects of tumor necrosis factor and other cytokines. Biotherapy 3: 143-158, 1991.

54. Grunfeld C, Zhao C, Fuller J, Pollack A, Moser A, Friedman J, and Feingold KR. Endotoxin and cytokines induce expression of leptin, the ob gene product, in hamsters. $J$ Clin Invest 97: 2152-2157, 1996. 
55. Hauner H, Bender M, Haastert B, and Hube F. Plasma concentrations of TNF- $\alpha$ and its soluble receptors in obese subjects. Int J Obes 22: 1239-1243, 1998.

56. Hauner H, Petruschke T, Russ M, Röhrig K, and Eckel J. Effects of tumour necrosis factor alpha (TNF) on glucose transport and lipid metabolism of newly-differentiated human fat cells in cell culture. Diabetologia 38: 764-771, 1995.

57. Hauner H, Röhrig K, and Petruschke T. Effects of epidermal growth factor (EGF), platelet-derived growth factor (PDGF) and fibroblast growth factor (FGF) on human adipocyte development and function. Eur J Clin Invest 25: 90-96, 1995.

58. Heaney ML and Golde DW. Soluble hormone receptors. Blood 82: 1945-1948, 1993.

59. Heid HW, Moll R, Schwetlick I, Rackwitz HR, and Keenan TW. Adipophilin is a specific marker of lipid accumulation in diverse cell types and diseases. Cell Tissue Res 294: 309-321, 1998.

60. Hirsch $\mathbf{J}$ and Batchelor B. Adipose tissue cellularity in human obesity. Clin Endocrinol Metab 5: 299-311, 1976.

61. Hotamisligil GS, Arner P, Atkinson RL, and Spiegelman BM. Differential regulation of the p80 of tumor necrosis factor receptor in human obesity and insulin resistance. Diabetes 46 : 451-455, 1997.

62. Hotamisligil GS, Arner P, Caro JF, Atkinson RL, and Spiegelman BM. Increased adipose tissue expression of tumor necrosis factor- $\alpha$ in human obesity and insulin resistance. $J$ Clin Invest 95: 2409-2415, 1995.

63. Hotamisligil GS, Johnson RS, Distel RJ, Ellis R, Papaioannou VE, and Spiegelman BM. Uncoupling of obesity from insulin resistance through a targeted mutation in aP2, the adipocyte fatty acid binding protein. Science 274: 1377-1379, 1996.

64. Hotamisligil GS, Peraldi P, Budavari A, Ellis R, White MF, and Spiegelman BM. IRS-1-mediated inhibition of insulin receptor tyrosine kinase activity in $\mathrm{TNF}-\alpha$ - and obesityinduced insulin resistance. Science 271: 665-668, 1996.

65. Hotamisligil GS, Shargill NS, and Spiegelman BM. Adipose expression of tumor necrosis factor- $\alpha$ : direct role in obesity-linked insulin resistance. Science 259: 87-91, 1993.

66. Hotta K, Funahashi T, Arita Y, Takahashi M, Mastsuda M, Okamoto Y, Iwahashi H, Kuriyama H, Maeda K, Nishida M, Kihara S, Sakai N, Nakajima T, Yamashita S, Hanafusa T, and Matsuzawa Y. Plasma concentrations of a novel, adipose-specific protein, adiponectin, in type 2 diabetic patients. Arterioscler Thromb Vasc Biol 20: 1595-1599, 2000.

67. Hu E, Liang P, and Spiegelman BM. AdipoQ is a novel adipose-specific gene dysregulated in obesity. J Biol Chem 271: 10697-10703, 1996

68. Hube F, Birgel M, Lee YM, and Hauner H. Expression pattern of tumour necrosis factor receptors in subcutaneous and omental human adipose tissue: role of obesity and noninsulin-dependent diabetes mellitus. Eur J Clin Invest 29: 672678, 1999.

69. Hube $\mathbf{F}$ and Hauner $\mathbf{H}$. The role of TNF- $\alpha$ in human adipose tissue: prevention of weight gain at the expense of insulin resistance? Horm Metab Res 31: 626-631, 1999.

70. Hube F, Lee YM, Röhrig K, and Hauner H. The phosphodiesterase inhibitor IBMX suppresses TNF- $\alpha$ expression in human adipocyte precursor cells: a possible explanation for its adipogenic effect. Horm Metab Res 31: 359-362, 1999.

71. Ihle JN and Kerr IM. Jaks and Stats in signaling by the cytokine receptor superfamily. Trends Genet 11: 69-74, 1995.

72. Imura H, Fukara J, and Mori T. Cytokines and endocrine function: an interaction between the immune and neuroendocrine systems. Clin Endocrinol 35: 107-115, 1997.

73. Iwanij V, Amos TM, and Billington CJ. Identification and characterization of the glucagon receptor from adipose tissue. Mol Cell Endocrinol 101: 257-261, 1994.

74. Janik JE, Curti BD, Considine RV, Rager HC, Powers GC, Alvord WG, Smith JW II, Gause BL, and Kopp WC. Interleukin $1 \alpha$ increases serum leptin concentrations in humans. J Clin Endocrinol Metab 82: 3084-3086, 1997.

75. Jensen MD. Lipolysis: contribution from regional fat. Annu Rev Nutr 17: 127-139, 1997.
76. Jones BH, Standridge MK, Taylor JW, and Moustaid N. Angiotensinogen gene expression in adipose tissue: analysis of obese models and hormonal and nutritional control. Am $J$ Physiol Regulatory Integrative Comp Physiol 273: R236-R242, 1997.

77. Jones SA, Horiuchi S, Topley N, Yamamoto N, and Fuller GM. The soluble interleukin 6 receptor: mechanisms of production and implications in disease. FASEB J 15: 43-58, 2001.

78. Juhan-Vague I and Alessi MC. PAI-1, obesity, insulin resistance and risk of cardiovascular events. Thromb Haemostasis 78: 656-660, 1997.

79. Kamei Y, Kawada T, Kazuki R, Ono T, Kato S, and Sugimoto E. Vitamin D receptor gene expression is up-regulated by 1,25-dihydroxyvitamin D3 in 3T3-L1 preadipocytes. Biochem Biophys Res Commun 193: 948-955, 1993.

80. Kanety H, Hemi R, Papa MZ, and Karasik A. Sphingomyelinase and ceramide suppress insulin-induced tyrosine phosphorylation of the insulin receptor substrate-1. J Biol Chem 271: 9895-9897, 1996.

81. Kern PA, Saghizadeh M, Ong JM, Bosch RJ, Deem R, and Simsolo RB. The expression of tumor necrosis factor in human adipose tissue. Regulation by obesity, weight loss, and relationship to lipoprotein lipase. J Clin Invest 95: 2111-2119, 1995.

82. Kieffer TJ and Habener JF. The adipoinsular axis: effects of leptin on pancreatic $\beta$-cells. Am J Physiol Endocrinol Metab 278: E1-E14, 2000.

83. Kim JK, Michael MD, Previs SF, Peroni OD, MauvaisJarvis F, Neschen S, Kahn BB, Kahn CR, and Shulman GI. Redistribution of substrates to adipose tissue promotes obesity in mice with selective insulin resistance in muscle. $J$ Clin Invest 105: 1791-1797, 2000.

84. Kim YB, Uotani S, Pierroz DD, Flier JS, and Kahn BB. In vivo administration of leptin activates signal transduction directly in insulin-sensitive tissues: overlapping but distinct pathways from insulin. Endocrinology 141: 2328-2339, 2000.

85. Kirchgessner TG, Uysal KT, Wiesbrock SM, Marino MW, and Hotamisligil GS. Tumor necrosis factor $\alpha$ contributes to obesity-related hyperleptinemia by regulating leptin release from adipocytes. J Clin Invest 100: 2777-2782, 1997.

86. Klebig ML, Wilkinson JE, Geisler JG, and Woychik RP. Ectopic expression of the agouti gene in transgenic mice causes obesity, features of type II diabetes and yellow fur. Proc Natl Acad Sci USA 92: 4728-4732, 1996.

87. Kopelman PG. Effects of obesity on fat topography: metabolic and endocrine determinants. In: Clinical Obesity (1st ed.), edited by Kopelman PG and Stock MJ. Oxford, UK: Blackwell Science, 1998, p. 158-175.

88. Kraemer FB, Laane C, Park B, and Sztalryd C. Lowdensity lipoprotein receptors in rat adipocytes: regulation with fasting. Am J Physiol Endocrinol Metab 266: E26-E32, 1994.

89. Kras KM, Hausman DB, and Martin RJ. Tumor necrosis factor- $\alpha$ stimulates cell proliferation in adipose tissue-derived stromal-vascular cell culture: promotion of adipose tissue expansion by paracrine growth factors. Obes Res 8: 186-193, 2000.

90. Kroder G, Bossenmaier B, Kellerer M, Capp E, Stoyanov B, Mühlhöfer A, Berti L, Horikoshi H, Ullrich A, and Häring H. Tumor necrosis factor- $\alpha$ - and hyperglycemia-induced insulin resistance. Evidence for different mechanisms and different effects on insulin signaling. J Clin Invest 97: 1471-1477, 1996.

91. Lafontan $\mathbf{M}$ and Berlan M. Fat cell adrenergic receptors and the control of white and brown fat cell function. J Lipid Res 34: 1057-1091, 1993.

92. Lechan RM. Update on thyroid releasing hormone. Thyroid Today 16: 1-11, 1993

93. Lee GH, Proenca R, Montez JM, Carroll K, Darvishzadeh JG, Lee JI, and Friedman JM. Abnormal splicing of the leptin receptor in diabetic mice. Nature 379: 632-635, 1996.

94. Li C and Friedman JM. Leptin receptor activation of SH2 domain containing protein tyrosine phosphatase 2 modulates Ob receptor signal transduction. Proc Natl Acad Sci USA 96: 9677-9682, 1999. 
95. Licinio J, Mantzoros C, Negrao AB, Cizza G, Wong ML, Bongiono PB, Chrousos GP, Karp B, Allen C, Flier JS, and Gold PW. Human leptin levels are pulsatile and inversely related to pituitary-adrenal function. Nature Med 3: 575-579, 1997.

96. Liu LS, Spelleken M, Röhrig K, Hauner H, and Eckel J. Tumor necrosis factor- $\alpha$ acutely inhibits insulin signaling in human adipocytes. Implication of the p80 tumor necrosis factor receptor. Diabetes 47: 515-522, 1998.

97. Löllmann B, Grüninger S, Stricker-Krongrad A, and Chiesi M. Detection and quantification of the leptin receptor splice variants $\mathrm{Ob}-\mathrm{Ra}, \mathrm{b}$, and e in different mouse tissues. Biochem Biophys Res Commun 238: 648-652, 1997.

98. Lord GM, Matarese G, Howard JK, Baker RJ, Bloom SR, and Lechler RI. Leptin modulates the T-cell immune response and reverses starvation-induced immunosuppression. Nature 394: 897-901, 1998

99. Lowell BB. PPARy: an essential regulator of adipogenesis and modulator of fat cell function. Cell 99: 239-242, 1999.

100. Machinal F, Dieudonne MN, Leneveu MC, Pecquery R, and Giudicelli $\mathbf{Y}$. In vivo and in vitro ob gene expression and leptin secretion in rat adipocytes: evidence for a regional specific regulation by sex steroid hormones. Endocrinology 140: 1567-1574, 1999.

101. Madej T, Boguski MS, and Bryant SH. Threading analysis suggests that the obese gene product may be a helical cytokine. FEBS Lett 373: 13-18, 1995.

102. Manne J, Argeson AC, and Siracusa LD. Mechanisms for the pleiotropic effects of the agouti gene. Proc Natl Acad Sci USA 92: 4721-4724, 1995.

103. Mantzoros CS. The role of leptin in human obesity and disease: a review of current evidence. Ann Intern Med 130: 671680, 1999.

104. Mantzoros CS, Moschos S, Avramopoulos I, Kaklamani V, Liolios A, Doulgerakis DE, Griveas I, Katsilambros N, and Flier JS. Leptin concentrations in relation to body mass index and the tumor necrosis factor- $\alpha$ system in humans. $J$ Clin Endocrinol Metab 82: 3408-3413, 1997.

105. Marques BG, Hausman DB, Latimer AM, Kras KM, Grossman BM, and Martin RJ. Insulin-like growth factor I mediates high-fat diet-induced adipogenesis in Osborne-Mendel rats. Am J Physiol Regulatory Integrative Comp Physiol 278: R654-R662, 2000

106. Maslowska M, Scantlebury T, Germinario R, and Cianflore K. Acute in vitro production of acylation stimulating protein in differentiated human adipocytes. J Lipid Res 38: $1-11,1997$.

107. Mavri A, Stegnar M, Krebs M, Sentocnik JT, Geiger M, and Binder BR. Impact of adipose tissue on plasma plasminogen activator inhibitor-1 in dieting obese women. Arterioscler Thromb Vasc Biol 19: 1582-1587, 1999.

108. McCann SM, Karanth S, Kamat A, Les Dees W, Lyson K, Gimeno M, and Rettori V. Induction by cytokines of the pattern of pituitary hormone secretion in infection. Neuroimmunomodulation 1: 2-13, 1994.

109. Mohamed-Ali V, Goodrick S, Bulmer K, Holly JM, Yudkin JS, and Coppack SW. Production of soluble tumor necrosis factor receptors by human subcutaneous adipose tissue in vivo. Am J Physiol Endocrinol Metab 277: E971-E975, 1999

110. Mohamed-Ali V, Goodrick S, Rawesh A, Katz DR, Miles JM, Yudkin JS, Klein S, and Coppack SW. Subcutaneous adipose tissue releases interleukin-6, but not tumor necrosis factor- $\alpha$, in vivo. J Clin Endocrinol Metab 82: 4196-4200, 1997.

111. Mohamed-Ali V, Pinkney JH, and Coppack SW. Adipose tissue as an endocrine and paracrine organ. Int $J$ Obes 22: 1145-1158, 1998.

112. Montague CT, Prins JB, Sanders L, Digby JE, and O'Rahilly S. Depot- and sex-specific differences in human leptin mRNA expression. Implications for the control of regional fat distribution. Diabetes 46: 342-347, 1997.

113. Morin CL, Eckel RH, Marcel T, and Pagliassotti MJ. High fat diets elevate tissue-derived tumor necrosis factor- $\alpha$ activity. Endocrinology 138: 4665-4671, 1997.
114. Nakashima K, Narazaki M, and Taga T. Overlapping and distinct signals through leptin receptor (OB-R) and a closely related cytokine signal transducer, gp130. FEBS Lett 401: 49-52, 1997.

115. Navre M and Ringold GM. Differential effects of fibroblast growth factor and tumor promoters on the initiation and maintenance of adipocyte differentiation. J Cell Biol 109: 1857$1863,1989$.

116. Nonogaki K, Fuller GM, Fuentes NL, Moser AH, Staprans I, and Grunfeld C. Interleukin-6 stimulates hepatic triglyceride secretion in rats. Endocrinology 136: 2143-2149, 1995.

117. O'Brien SN, Welter BH, Mantzke KA, and Price TM. Identification of progesterone receptor in human subcutaneous adipose tissue. J Clin Endocrinol Metab 83: 509-513, 1998.

118. Ofei F, Hurel S, Newkirk J, Sopwith M, and Taylor R. Effects of an engineered human anti-TNF- $\alpha$ antibody (CDP571) on insulin sensitivity and glycemic control in patients with NIDDM. Diabetes 45: 881-885, 1996.

119. Papanicolaou DA, Petrides JS, Tsigos C, Bina S, Kalogeras KT, Wilder R, Gold PW, Deuster PA, and Chrousos GP. Exercise stimulates interleukin-6 secretion: inhibition by glucocorticoids and correlation with catecholamines. $A m J$ Physiol Endocrinol Metab 271: E601-E605, 1996.

120. Paz K, Hemi R, LeRoith D, Karasik A, Elhanany E, and Kanety H. A molecular basis for insulin resistance. Elevated serine/threonine phosphorylation of IRS-1 and IRS-2 inhibits their binding to juxtamembrane region of the insulin receptor and impairs their ability to undergo insulin-induced thyrosine phosphorylation. J Biol Chem 272: 29911-29918, 1997.

121. Peraldi P, Hotamisligil GS, Buurman WA, White MF, and Spiegelman BM. Tumor necrosis factor (TNF)-alpha inhibits insulin signaling through stimulation of the p55 TNF receptor and activation of sphyngomyelinase. J Biol Chem 271: 1301813022, 1996.

122. Petruschke $\mathbf{T}$ and Hauner $\mathbf{H}$. Tumor necrosis factor-alpha prevents the differentiation of human adipocyte precursor cells and causes delipidation of newly developed fat cells. $J$ Clin Endocrinol Metab 76: 742-747, 1993.

123. Pfeiffer A, Janot J, Möhlig M, Ristow M, Rochlitz H, Busch K, Schatz H, and Schifferdecker E. Circulating tumor necrosis factor $\alpha$ is elevated in male but not in female patients with type II diabetes mellitus. Horm Metab Res 29: 111-114, 1997

124. Pickup JC, Chusney GD, Thomas SM, and Burt D. Plasma interleukin-6, tumour necrosis factor $\alpha$ and blood cytokine production in type 2 diabetes. Life Sci 67: 291-300, 2000.

125. Pinkney JH, Coppack SW, and Mohamed-Ali V. Effect of isoprenaline on plasma leptin and lipolysis in humans. Clin Endocrinol 48: 407-411, 1998.

126. Pober JS and Cotran RS. Cytokines and endothelial cell biology. Physiol Rev 70: 427-451, 1990.

127. Potts JL, Coppack SW, Fisher RM, Humphreys SM, Gibbons GF, and Frayn KN. Impaired postprandial clearance of triacylglycerol-rich lipoproteins in adipose tissue in obese subjects. Am J Physiol Endocrinol Metab 268: E588-E594, 1995.

128. Prins JB, Niesler CU, Winterford CM, Bright NA, Siddle K, O'Rahilly S, Walker N, and Cameron DP. Tumor necrosis factor- $\alpha$ induces apoptosis of human adipose cells. Diabetes 46: 1939-1944, 1997

129. Ramsay TG. Fat cells. Endocrinol Metab Clin North Am 25: 847-879, 1996.

130. Rettori V, Gimeno MF, Gonzalez MC, and McCann SM. Interleukin $1 \alpha$ inhibits prostaglandin $\mathrm{E}_{2}$ to suppress pulsatile release of luteinizing hormone but not follicle stimulating hormone. Proc Natl Acad Sci USA 88: 2863-2867, 1991.

131. Ribière C, Jaubert AM, Gaudiot N, Sabourault D, Marcus ML, Boucher JL, Denis-Henriot D, and Giudicelli Y. White adipose tissue nitric oxide synthase: a potential source for NO production. Biochem Biophys Res Commun 222: 706712,1996

132. Rigden DJ, Jellyman AE, Frayn KN, and Coppack SW. Human adipose tissue glycogen levels and responses to carbohydrate feeding. Eur J Clin Nutr 44: 689-692, 1990. 
133. Saito T, Yasukawa K, Suzuki H, Futatsugi K, Fukunaga T, Yokomizo C, Kishihara Y, Fukui H, Ohsugi Y, Yawata H, Kobayashi I, Hirano T, Taga T, and Kishimoto $T$. Preparation of soluble murine IL-6 receptor and anti-murine IL-6 receptor antibodies. J Immunol 147: 168-173, 1991.

134. Sakaue S, Nishihira J, Hirokawa J, Yoshimura H, Honda T, Aoki K, Tagami S, and Kawakami Y. Regulation of macrophage migration inhibitory factor (MIF) expression by glucose and insulin in adipocytes in vitro. Mol Med 5: 361-371, 1999.

135. Salter AM, Fong BS, Jimenez J, Rotstein L, and Angel A. Regional variation in high-density lipoprotein binding to human adipocyte plasma membranes of massively obese subjects. Eur J Clin Invest 17: 16-22, 1987.

136. Samad F and Loskuttof DJ. Tissue distribution and regulation of plasminogen activator inhibitor-1 in obese mice. $\mathrm{Mol}$ Med 2: 568-582, 1996.

137. Samad F, Yamamoto K, Pandey M, and Loskuttof DJ. Elevated expression of transforming growth factor- $\beta$ in adipose tissue from obese mice. Mol Med 3: 37-48, 1997.

138. Sarraf P, Frederich RC, Turner EM, Ma G, Jaskowiak NT, Rivet DJ, Flier JS, Lowell BB, Fraker DL, and Alexander HR. Multiple cytokines and acute inflammation raise mouse leptin levels: potential role in inflammatory anorexia. J Exp Med 185: 171-175, 1997.

139. Sarzani R, Paci VM, Zingaretti CM, Pierleoni C, Cinti S, Cola G, Rappelli A, and Dessi-Fulgheri P. Fasting inhibits natriuretic peptides clearance receptor expression in rat adipose tissue. J Hypertens 13: 1241-1246, 1995.

140. Scherer PE, Williams S, Fogliano M, Baldini G, and Lodish HF. A novel serum protein similar to C1q, produced exclusively in adipocytes. J Biol Chem 270: 26746-26749, 1996.

141. Schmidt W, Poll-Jordan G, and Loffler G. Adipose conversion of 3T3-L1 cells in a serum-free culture system depends on epidermal growth factor, insulin-like growth factor I, corticosterone, and cyclic AMP. J Biol Chem 265: 15489-15495, 1990.

142. Schreyer SA, Streamson CC, and LeBoeuf RC. Obesity and diabetes in TNF- $\alpha$ receptor-deficient mice. J Clin Invest 102: 402-411, 1998.

143. Serrero G and Lepak N. Endocrine and paracrine negative regulators of adipose differentiation. Int J Obes 20, Suppl 3: S58-S64, 1996.

144. Shaughnessy S, Smith ER, Kodukula S, Storch J, and Fried SK. Adipocyte metabolism in adipocyte fatty acid binding protein knockout $\left(\mathrm{aP}^{-/-}\right)$mice after short-term high-fat feeding. Diabetes 49: 904-911, 2000.

145. Shimabukuro M, Koyama K, Chen G, Wang MY, Trieu F, Lee Y, Newgard CB, and Unger RH. Direct antidiabetic effect of leptin through triglyceride depletion of tissues. Proc Natl Acad Sci USA 94: 4637-4641, 1997.

146. Shimomura I, Funahashi T, Takahashi M, Maeda K, Kotani K, Nakamura T, Yamashita S, Miura M, Fukuda Y, Takemura K, Tokunaga K, and Matsuzawa Y. Enhanced expression of PAI-1 in visceral fat: possible contributor to vascular disease in obesity. Nat Med 2: 800-803, 1996.

147. Sierra-Honigmann MR, Nath AK, Murakami C, GarcíaCardeña G, Papapetropoulos A, Sessa WC, Madge LA, Schechner JS, Schwabb MB, Polverini PJ, and FloresRiveros JR. Biological action of leptin as an angiogenic factor. Science 281: 1683-1686, 1998.

148. Sniderman AD and Cianflore K. The adipsin-ASP pathway and regulation of adipocyte function. Ann Intern Med 26: 389$393,1994$.

149. Sniderman AD, Cianflore K, and Eckel RH. Levels of acylation stimulating protein in obese women before and after moderate weight loss. Int J Obes 15: 333-336, 1991.

150. Soderberg S, Olsson T, Eliasson M, Johnson O, and Ahren B. Plasma leptin levels are associated with abnormal fibrinolysis in men and postmenopausal women. J Intern Med 245: 533-543, 1999.

151. Spiegelman BM and Flier JS. Adipogenesis and obesity: rounding out the big picture. Cell 87: 377-389, 1996.
152. Spiegelman BM and Green $\mathbf{H}$. Control of specific protein biosynthesis during the adipose conversion of 3T3 cells. J Biol Chem 255: 8811-8818, 1980.

153. Spiegelman BM, Choy L, Hotamisligil GS, Graves RA, and Tontonoz P. Regulation of adipocyte gene expression in differentiation and syndromes of obesity/diabetes. J Biol Chem 268: 6823-6826, 1993.

154. Sporn MB, Roberts AB, Wakefield LM, and de Crombrugghe $\mathbf{B}$. Some recent advances in the chemistry and biology of transforming growth factor- $\beta$. J Cell Biol 105: 1039-1045, 1987.

155. Stephens JM, Lee J, and Pilch PF. Tumor necrosis factor$\alpha$-induced insulin resistance in 3T3-L1 adipocytes is accompanied by a loss of insulin receptor substrate-1 and GLUT4 expression without a loss of insulin receptor-mediated signal transduction. J Biol Chem 272: 971-976, 1997.

156. Stephens JM and Pekala PH. Transcriptional repression of Glut-4 and C/EBP genes in 3T3-L1 adipocytes by tumor necrosis factor alpha. J Biol Chem 266: 21839-21845, 1992

157. Stoyan T, Michaelis U, Schooltink H, Van-Dam M, Rudolph R, Heinrich PC, and Rose-John S. Recombinant soluble human interleukin-6 receptor. Expression in Escherichia coli, renaturation and purification. Eur J Biochem 216: 239-245, 1993

158. Strassmann G, Fong M, Kenney JS, and Jacob CO. Evidence for the involvement of interleukin 6 in experimental cancer cachexia. J Clin Invest 89: 1681-1684, 1992.

159. Szanto I and Kahn CR. Selective interaction between leptin and insulin signaling pathways in a hepatic cell line. Proc Natl Acad Sci USA 97: 2355-2360, 2000.

160. Taga T, Hibi M, Hirata Y, Yamasaki K, Yasukawa K, Matsuda T, Hirano T, and Kishimoto T. Interleukin-6 triggers the association of its receptor with a possible signal transducer, gp130. Cell 58: 573-581, 1989.

161. Tartaglia LA. The leptin receptor. J Biol Chem 272: 60936096, 1997.

162. Taylor JE, Scott CD, and Baxter RC. Comparison of receptors for insulin-like growth factor II from various rat tissues. $J$ Endocrinol 115: 35-41, 1987.

163. Tiebel O, Oka K, Robinson K, Sullivan M, Martinez J, Nakamuta M, Ishimura-Oka K, and Chan L. Mouse very low-density lipoprotein receptor (VLDLR): gene structure, tissue-specific expression and dietary and developmental regulation. Atherosclerosis 145: 239-251, 1999.

164. Torres-Márquez ME, Romero-Avila MT, González-Espinosa C, and Garcia-Sainz J. A characterization of rat white fat cell $\alpha_{1 \mathrm{~B}}$-adrenoceptors. Mol Pharmacol 42: 403-406, 1992.

165. Torti FM, Dieckmann B, Beutler B, Cerami A, and Ringold GM. A macrophage factor inhibits adipocyte gene expression: an in vitro model of cachexia. Science 229: 867-869, 1985.

166. Trayhurn P. New insights into the development of obesity: obese genes and the leptin system. Proc Nutr Soc 55: 783-791, 1996.

167. Tsigos C, Papanicolaou DA, Mitsiadis CS, Kyrou I, and Chrousos GP. Dose effects of recombinant interleukin-6 on pituitary hormone secretion and energy expenditure. Neuroendocrinology 66: 54-62, 1997.

168. Uysal KT, Wiesbrock SM, and Hotamisligil GS. Functional analysis of tumor necrosis factor (TNF) receptors in TNF- $\alpha-$ mediated insulin resistance in genetic obesity. Endocrinology 139: 4832-4838, 1998.

169. Uysal KT, Wiesbrock SM, Marino MW, and Hotamisligil GS. Protection from obesity-induced insulin resistance in mice lacking TNF-alpha function. Nature 389: 610-614, 1997.

170. Vague P, Juhan-Vague I, Aillaud MF, Badier C, Viard R, Alessi MC, and Collen D. Correlation between blood fibrinolytic activity, plasminogen activator inhibitor level, plasma insulin level, and relative body weight in normal and obese subjects. Metabolism 35: 250-253, 1986.

171. Van Harmelen V, Elizalde M, Ariapart P, BergstedtLindqvist S, Reynisdottir S, Hoffstedt J, Lundkvist I, Bringman S, and Arner P. The association of human adipose 
angiotensinogen gene expression with abdominal fat distribution in obesity. Int J Obes 24: 673-678, 2000.

172. Van Snick J. Interleukin-6: an overview. Annu Rev Immunol 8: 253-278, 1996.

173. Van-Zee KJ, Kohno T, Fischer E, Rock CS, Moldawer LL, and Lowry SF. Tumor necrosis factor soluble receptors circulate during experimental and clinical inflammation and can protect against excessive tumor necrosis factor alpha in vitro and in vivo. Proc Natl Acad Sci USA 89: 4845-4849, 1992.

174. Vassaux G, Gaillard D, Mari B, Ailhaud G, and Negrel R. Differential expression of adenosine A1 and A2 receptors in preadipocytes and adipocytes. Biochem Biophys Res Commun 193: 1123-1130, 1993.

175. Vgontzas AN, Papanicolaou DA, Bixler EO, Kales A, Tyson $\mathbf{K}$, and Chrousos GP. Elevation of plasma cytokines in disorders of excessive daytime sleepiness: role of sleep disturbance and obesity. J Clin Endocrinol Metab 82: 1313-1316, 1997.

176. Vikman K, Carlsson B, Billig H, and Eden S. Expression and regulation of growth hormone $(\mathrm{GH})$ receptor messenger ribonucleic acid (mRNA) in rat adipose tissue, adipocytes, and adipocyte precursor cells: GH regulation of GH receptor mRNA. Endocrinology 129: 1155-1161, 1991.

177. Villarroya F, Giralt M, and Iglesias R. Retinoids and adipose tissues: metabolism, cell differentiation and gene expression. Int J Obes 23: 1-6, 1999.

178. Wabitsch M, Hauner H, Heinze E, and Teller WM. The role of growth hormone/insulin growth factors in adipocyte differentiation. Metabolism 44: 45-49, 1995.

179. Wang J, Liu R, Hawkins M, Barzilai N, and Rossetti L. A nutrient-sensing pathway regulates leptin gene expression in muscle and fat. Nature 393: 684-688, 1998.

180. Wang MY, Lee Y, and Unger RH. Novel form of lipolysis induced by leptin. J Biol Chem 274: 17541-17544, 1998.

181. Wang ZW, Zhou YT, Lee Y, Higa M, Kalra SP, and Unger RH. Hyperleptinemia depletes fat from denervated fat tissue. Biochem Biophys Res Commun 260: 653-657, 1999.

182. Wiman B, Chmielewska J, and Ranby M. Inactivation of tissue plasminogen activator in plasma: demonstration of a complex with a new rapid inhibitor. $J$ Biol Chem 259: 36443647, 1984.

183. Wootan MG, Bernlohr DA, and Storch J. Mechanism of fluorescent fatty acid transfer from adipocyte fatty acid binding protein to membranes. Biochemistry 32: 8622-8627, 1993.

184. Xing H, Northrop JP, Grove JR, Kilpatrick KE, Su JL, and Ringold GM. TNF alpha-mediated inhibition and reversal of adipocyte differentiation is accompanied by suppressed expression of PPAR gamma without effects on Pref-1 expression. Endocrinology 138: 2776-2783, 1997.

185. Yasruel Z, Cianflore K, Sniderman AD, Rosenbloom M, Walsh MJ, and Rodriguez MA. Effect of acylation stimulat- ing protein on the triacylglycerol synthetic pathway of human adipose tissue. Lipids 26: 495-499, 1991.

186. Yasukawa K, Futatsugi K, Saito T, Yawata H, Narazaki M, Suzuki H, Taga T, and Kishimoto T. Association of recombinant soluble IL-6-signal transducer, gp130, with a complex of IL-6 and soluble IL-6 receptor, and establishment of an ELISA for soluble gp130. Immunol Lett 31: 123-130, 1992.

187. Yip RG, Boylan MO, Kieffer TJ, and Wolfe MM. Functional GIP receptors are present on adipocytes. Endocrinology 139: 4004-4007, 1998.

188. Yip RG and Wolfe MM. GIP biology and fat metabolism. Life Sci 66: 91-103, 2000.

189. Yudkin JS, Kumari M, Humphries SE, and Mohamed-Ali V. Inflammation, obesity, stress and coronary heart disease: is interleukin-6 the link? Atherosclerosis 148: 209-214, 2000.

190. Zakrzewska KE, Cusin I, Sainsbury A, RohnerJeanrenaud F, and Jeanrenaud B. Glucocorticoids as counterregulatory hormones of leptin: toward an understanding of leptin resistance. Diabetes 46: 717-719, 1997.

191. Zemel MB, Kim JH, Woychik RP, Michaud EJ, Kadwell SH, Patel IR, and Wilkinson WO. Agouti regulation of intracellular calcium: role in insulin resistance of viable yellow mice. Proc Natl Acad Sci USA 92: 4733-4737, 1995.

192. Zhang B, Berger J, Hu E, Szalkowski D, White-Carrington S, Spiegelman BM, and Moller DE. Negative regulation of peroxisome proliferator-activated receptor-gamma gene expression contributes to the antiadipogenic effects of tumor necrosis factor- $\alpha$. Mol Endocrinol 10: 1457-1466, 1996.

193. Zhang F, Basinski MB, Beals JM, Briggs SL, Churgay LM, Clawson DK, DiMarchi RD, Furman TC, Hale JE, Hsiung HM, Schoner BE, Smith DP, Zhang XY, Wery JP, and Schevitz RW. Crystal structure of the obese protein leptinE100. Nature 387: 206-209, 1997.

194. Zhang HH, Kumar S, Barnett AH, and Eggo MC. Tumour necrosis factor- $\alpha$ exerts dual effects on human adipose leptin synthesis and release. Mol Cell Endocrinol 159: 79-88, 2000.

195. Zhang Y, Olbort M, Schwarzer K, Nuesslein-Hildesheim B, Nicolson M, Murphy E, Kowalski TJ, Schmidt I, and Leibel RL. The leptin receptor mediates apparent autocrine regulation of leptin gene expression. Biochem Biophys Res Commun 240: 492-495, 1997.

196. Zhang Y, Proenca R, Maffei M, Barone M, Leopold L, and Friedman JM. Positional cloning of the mouse obese gene and its human homologue. Nature 372: 425-432, 1994.

197. Zorad S, Fickova M, Zelezna B, Macho L, and Kral JG. The role of angiotensin II and its receptors in regulation of adipose tissue metabolism and cellularity. Gen Physiol Biophys 14: 383-391, 1995.

198. Zumbach MS, Boehme MWJ, Wahl P, Stremmel W, Ziegler R, and Nawroth PP. Tumor necrosis factor increases serum leptin levels in humans. J Clin Endocrinol Metab 82: 4080-4082, 1997. 